\title{
Geochronologic Age Constraints on Tectonostratigraphic Units of the Central Virginia Piedmont, USA
}

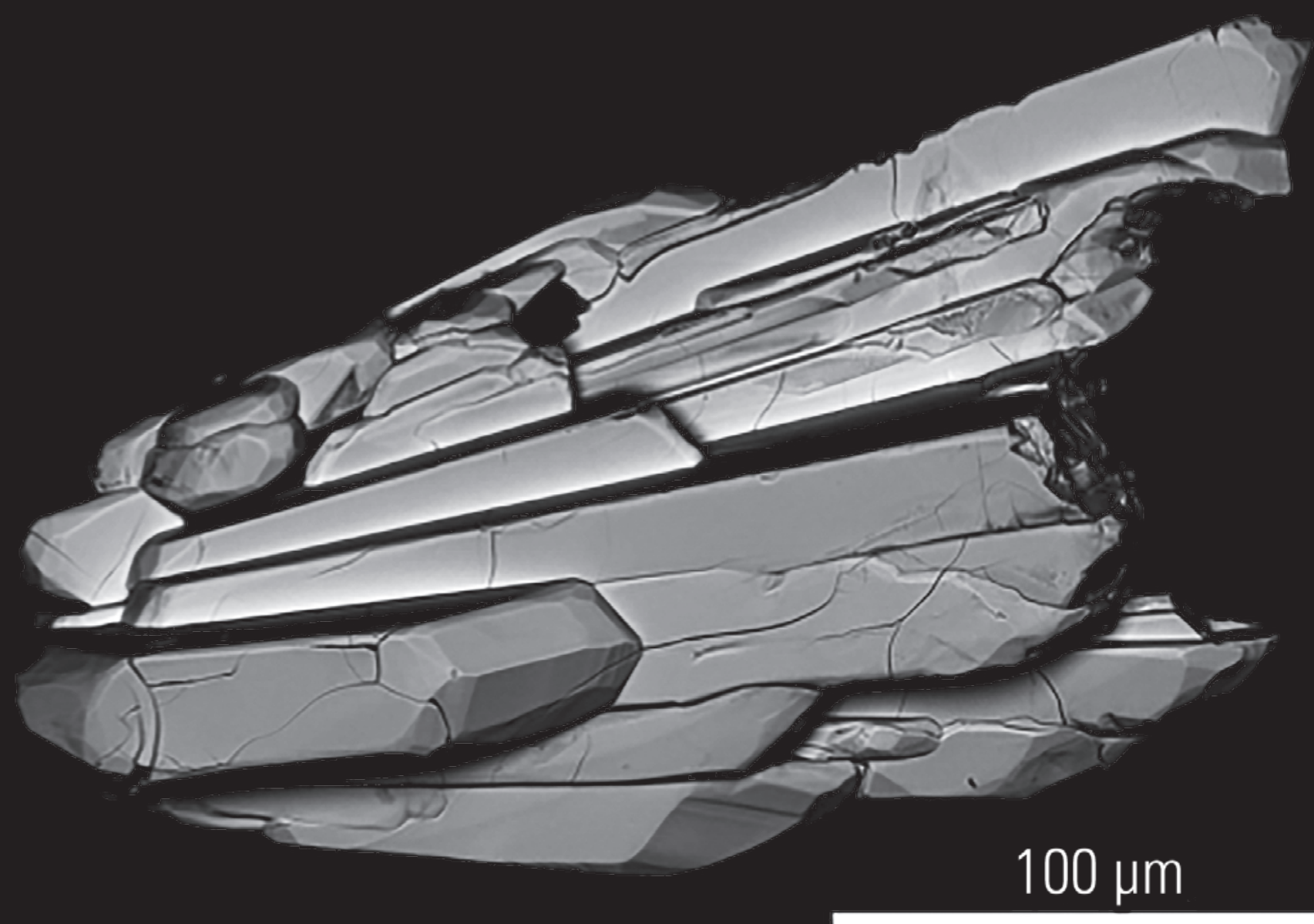

Professional Paper 1861 
Cover. Scanning electron microscopy-back-scatter electron detector image of a zircon aggregate from biotite-muscovite migmatitic paragneiss at the northern terminus of the Elk Hill Complex, central Virginia Piedmont. Image captured by Ryan J. McAleer, U.S. Geological Survey, using a Hitachi SU5000 field emission scanning electron microscope. 


\section{Geochronologic Age Constraints on Tectonostratigraphic Units of the Central Virginia Piedmont, USA}

By Mark W. Carter, Ryan J. McAleer, Christopher S. Holm-Denoma,

David B. Spears, Sean P. Regan, William C. Burton, and Nick H. Evans

Professional Paper 1861 


\title{
U.S. Department of the Interior DAVID BERNHARDT, Secretary
}

\author{
U.S. Geological Survey \\ James F. Reilly II, Director
}

U.S. Geological Survey, Reston, Virginia: 2020

For more information on the USGS - the Federal source for science about the Earth, its natural and living resources, natural hazards, and the environment-visit https://www.usgs.gov or call 1-888-ASK-USGS.

For an overview of USGS information products, including maps, imagery, and publications, visit https://store.usgs.gov.

Any use of trade, firm, or product names is for descriptive purposes only and does not imply endorsement by the U.S. Government.

Although this information product, for the most part, is in the public domain, it also may contain copyrighted materials as noted in the text. Permission to reproduce copyrighted items must be secured from the copyright owner.

Suggested citation:

Carter, M.W., McAleer, R.J., Holm-Denoma, C.S., Spears, D.B., Regan, S.P., Burton, W.C., and Evans, N.H., 2020, Geochronologic age constraints on tectonostratigraphic units of the central Virginia Piedmont, USA: U.S. Geological Survey Professional Paper 1861, 28 p., https://doi.org/10.3133/pp1861. 


\section{Acknowledgments}

The authors would like to thank the many landowners who gave us access to their properties during geologic mapping and sample collection, especially Pembroke Pettit, Christian Goodwin, and Selene Deike. We would also like to thank Arthur Merschat, Wright Horton, Greg Walsh, and Randy Orndorff (U.S. Geological Survey) and Brent Owens (College of William and Mary) for their thorough reviews, which greatly improved an earlier version of this manuscript. 


\section{Contents}

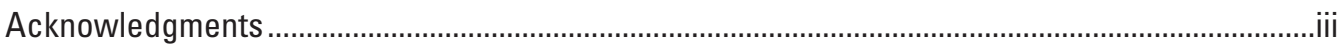

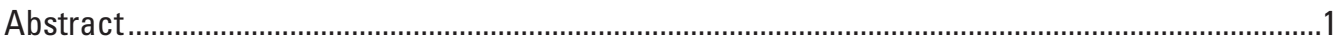

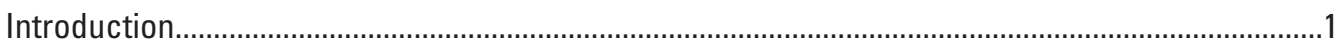

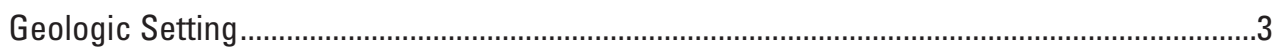

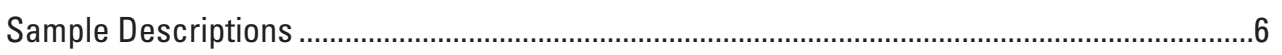

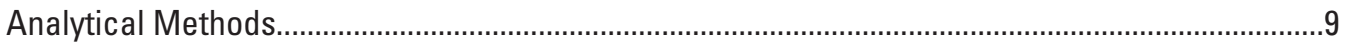

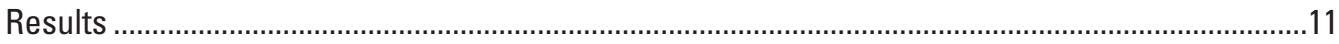

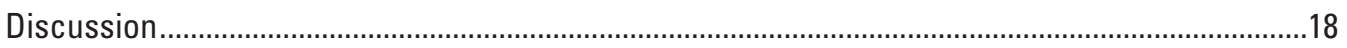

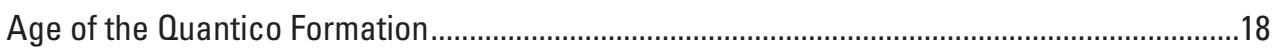

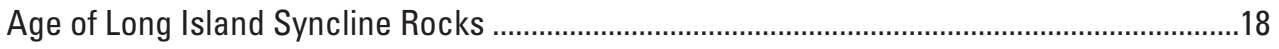

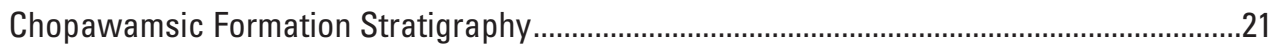

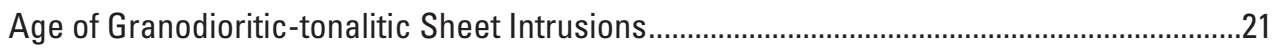

Metamorphic and Structural Considerations Along the East Flank of the Chopawamsic

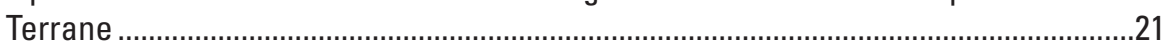

Conclusions

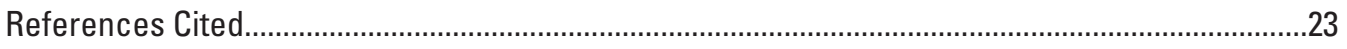

Appendix 1. Laser Ablation-Inductively Coupled Plasma-Mass Spectrometry (LA-ICP-MS)

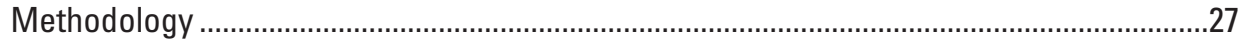

Appendix 2. Secondary Ionization Mass Spectrometry Methodology.........................................27 


\section{Figures}

1. Map showing location of study area in $A$, the Appalachian orogen and $B$, a generalized geologic map of Virginia... .2

2. Map showing regional bedrock geology map of the central Virginia Piedmont................5

3. Photographs of rocks and structures from the central Virginia Piedmont .......................8

4. Plots of laser ablation-inductively coupled plasma-mass spectrometry detrital zircon data and sensitive high-resolution ion microprobe detrital zircon data from central Virginia Piedmont samples collected during this study.....

5. Scanning electron microscopy-back-scatter electron detector and scanning electron microscopy-cathodoluminescence images of representative zircon grains and plots of isotopic data from the samples analyzed on the Stanford/ U.S. Geological Survey sensitive high-resolution ion microprobe-reverse geometry

6. Scanning electron microscopy-back-scatter electron detector and scanning electron microscopy-cathodoluminescence images of representative zircon grains and plots of isotopic data from the samples analyzed on the Stanford/ U.S. Geological Survey sensitive high-resolution ion microprobe-reverse geometry

7. Plane polarized light, scanning electron microscopy-back-scatter electron detector and photoluminescence images of representative zircon grains from sample BK601 analyzed on the Stanford/U.S. Geological Survey sensitive high-resolution ion microprobe-reverse geometry.....

8. Plots of isotopic data from sample BK601 analyzed on the Stanford/U.S. Geological

Survey sensitive high-resolution ion microprobe-reverse geometry.

9. Comparative relative probability plots of detrital zircon data from samples dated by laser ablation-inductively coupled plasma-mass spectrometry and sensitive high-resolution ion microprobe-reverse geometry during this study, with published data from the central Piedmont in Virginia and Maryland.

10. Schematic diagram of Chopawamsic Formation stratigraphy in relation to overlying units and intrusive rocks in the central Virginia Piedmont, based on field relations and geochronology...

\section{Tables}

1. Summary of sample locations, dating methods, and age results of this study.

2. Isotopic data for all analyses by laser ablation-inductively coupled plasmamass spectrometry at the U.S. Geological Survey Central Mineral and Environmental Resources Science Center Isotope Laboratory in Denver, Colorado available online

3. Isotopic data for all analyses by secondary ionization mass spectrometry on the U.S. Geological Survey/Stanford sensitive high-resolution ion microprobe-reverse geometry available online 


\section{Conversion Factors}

International System of Units to U.S. customary units

\begin{tabular}{|c|c|c|}
\hline Multiply & By & To obtain \\
\hline \multicolumn{3}{|c|}{ Length } \\
\hline micrometer $(\mu \mathrm{m})$ & 0.00003937 & inch (in.) \\
\hline centimeter $(\mathrm{cm})$ & 0.3937 & inch (in.) \\
\hline millimeter (mm) & 0.03937 & inch (in.) \\
\hline meter $(\mathrm{m})$ & 3.281 & foot $(\mathrm{ft})$ \\
\hline kilometer $(\mathrm{km})$ & 0.6214 & mile (mi) \\
\hline \multicolumn{3}{|c|}{ Area } \\
\hline square centimeter $\left(\mathrm{cm}^{2}\right)$ & 0.001076 & square foot $\left(\mathrm{ft}^{2}\right)$ \\
\hline square meter $\left(\mathrm{m}^{2}\right)$ & 10.76 & square foot $\left(\mathrm{ft}^{2}\right)$ \\
\hline square centimeter $\left(\mathrm{cm}^{2}\right)$ & 0.1550 & square inch $\left(\mathrm{in}^{2}\right)$ \\
\hline \multicolumn{3}{|c|}{ Volume } \\
\hline cubic centimeter $\left(\mathrm{cm}^{3}\right)$ & 0.06102 & cubic inch $\left(\mathrm{in}^{3}\right)$ \\
\hline \multicolumn{3}{|c|}{ Flow rate } \\
\hline liter per second $(\mathrm{L} / \mathrm{s})$ & 15.85 & gallon per minute (gal $/ \mathrm{min}$ ) \\
\hline liter per minute (L/min) & 0.2642 & gallon per minute (gal/min) \\
\hline \multicolumn{3}{|c|}{ Density } \\
\hline gram per cubic centimeter $\left(\mathrm{g} / \mathrm{cm}^{3}\right)$ & 62.4220 & pound per cubic foot $\left(\mathrm{lb} / \mathrm{ft}^{3}\right)$ \\
\hline \multicolumn{3}{|c|}{ Energy } \\
\hline joule $(\mathrm{J})$ & 0.738 & foot-pound $(\mathrm{ft} \cdot \mathrm{lb})$ \\
\hline
\end{tabular}

\section{Abbreviations}

$\begin{array}{ll}\text { 3DEP } & \text { Three-Dimensional Elevation Program } \\ \text { BSE } & \text { back-scatter electron } \\ \text { CL } & \text { cathodoluminescence } \\ \text { CVSZ } & \text { Central Virginia Seismic Zone } \\ \text { Ga } & \text { billion years old } \\ \text { ID } & \text { isotope dilution } \\ \text { M } & \text { magnitude } \\ \text { Ma } & \text { million years old } \\ \text { MSWD } & \text { mean square of weighted deviates } \\ \text { LA-ICP-MS } & \text { laser ablation-inductively coupled plasma-mass spectrometry } \\ \text { LST } & \text { lithium heteropolytungstate } \\ \text { PPL } & \text { plane polarized light } \\ \text { ppm } & \text { parts per million } \\ \text { SHRIMP-RG } & \text { sensitive high-resolution ion microprobe-reverse geometry } \\ \text { TIMS } & \text { thermal ionization mass spectrometry } \\ \text { USGS } & \text { U.S. Geological Survey } \\ \text { UV } & \text { ultraviolet light } \\ < & \text { less than } \\ > & \text { greater than }\end{array}$




\title{
Geochronologic Age Constraints on Tectonostratigraphic Units of the Central Virginia Piedmont, USA
}

\author{
By Mark W. Carter ${ }^{1}$, Ryan J. McAleer ${ }^{1}$, Christopher S. Holm-Denoma', David B. Spears², Sean P. Regan², \\ William C. Burton', and Nick H. Evans ${ }^{4}$
}

\begin{abstract}
New geologic mapping coupled with uranium-lead $(\mathrm{U}-\mathrm{Pb})$ zircon geochronology (sensitive high-resolution ion microprobe-reverse geometry [SHRIMP-RG] and laser ablation-inductively coupled plasma-mass spectrometry [LA-ICP-MS]) analyses of 10 samples, provides new constraints on the tectonostratigraphic framework of the central Virginia Piedmont. Detrital zircon analysis confirms that the Silurian-Devonian Quantico Formation is a postorogenic successor basin, with zircons derived primarily from Ordovician Chopawamsic Formation volcanic rocks. Detrital zircons from strata of the Long Island syncline, previously mapped as a separate successor basin, have a peri-Gondwanan component distinct from Laurentian-sourced rocks of the Potomac terrane to the west. Volcanism of the Chopawamsic Formation spanned at least 14 million years during the Ordovician. The Chopawamsic Formation contains sheet-like Late OrdovicianSilurian granodioritic and tonalitic intrusions that were once mapped as Carboniferous. Biotite-muscovite migmatitic paragneiss, which borders the Chopawamsic Formation on its southeast side and also occurs east of the Lakeside fault, preserves evidence of Silurian deformation and metamorphism, with a Carboniferous (Alleghanian) overprint. Limited SHRIMP-RG analysis of detrital zircons from this paragneiss yields a Laurentian (Mesoproterozoic) signature, which suggests that the structurally concordant contact between volcanic rocks of the Chopawamsic Formation and paragneiss is either a pre-Alleghanian fault or an unconformity.
\end{abstract}

\footnotetext{
${ }^{1}$ U.S. Geological Survey.

${ }^{2}$ Virginia Department of Mines, Minerals and Energy.

${ }^{3}$ University of Alaska-Fairbanks.

${ }^{4}$ Center for Sustainable Groundwater.
}

\section{Introduction}

Precision uranium-lead (U-Pb) zircon geochronology is a critical tool in conjunction with detailed geologic mapping to provide ages of rock units and their mineral constituents to bracket regional tectonic events. This is particularly true in the Piedmont Province of central Virginia (figs. 1 and 2), where metamorphic rocks in the Appalachian hinterland record tectonic events that are separated by just a few million years (for example, Sinha and others, 2012; Hughes and others, 2013). The regional structure is of special interest because of its relation to the historically active Central Virginia Seismic Zone (CVSZ), including the epicentral region of the 2011 magnitude (M)5.8 Mineral, Virginia, earthquake (Horton and Williams, 2012).

To better understand the regional framework for seismic risk assessment, cooperative detailed geologic mapping across nine 7.5-minute quadrangles in the central Virginia Piedmont was conducted by the U.S. Geological Survey and Virginia Department of Mines, Minerals and Energy, Division of Geology and Mineral Resources following the 2011 Mineral, Virginia, earthquake. This study builds on earlier mapping by Pavlides $(1981,1989,1990)$ in the northern Virginia Piedmont, Spears (2011) along the James River to the south, and Hopkins (1960) and Hughes (2014) in the epicentral area of the 2011 earthquake.

We used both sensitive high-resolution ion microprobereverse geometry (SHRIMP-RG) and laser ablation-inductively coupled plasma-mass spectrometry (LA-ICP-MS) U-Pb zircon geochronology to help answer three outstanding questions in this geologically complex region. (1) Can stratigraphic succession be established within the Ordovician Chopawamsic Formation? (2) When was the onset of the postorogenic successor basin development above or near the volcanic arc represented by the Chopawamsic Formation? (3) What was the timing of deformation and metamorphism in the easternmost 


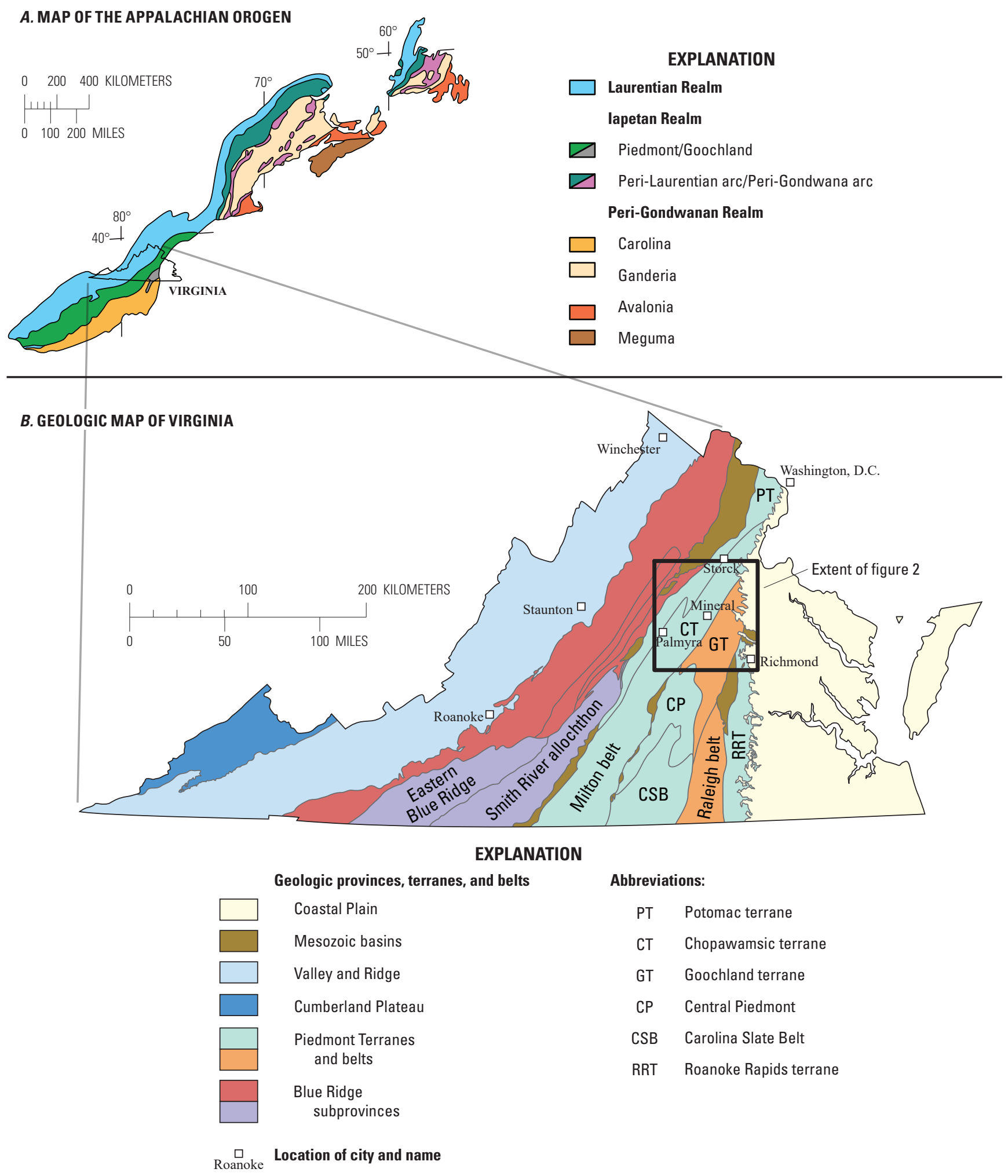

Figure 1. Location of study area in $A$, the Appalachian orogen (modified from Hibbard and others, 2006) and $B$, a generalized geologic map of Virginia (modified from Virginia Division of Mineral Resources, 1993). Inset box on the geologic map of Virginia denotes area in figure 2. 
extent of the Chopawamsic Formation, and how did these events relate to the emplacement and juxtaposition of rocks of the Elk Hill Complex and Goochland terrane along the Lakeside and Spotsylvania fault zones?

\section{Geologic Setting}

A west-to-east traverse across the central Virginia Piedmont intersects several major rock units of varying age and crustal affinity (fig. 2). In the west, rocks of the early Paleozoic Potomac terrane (Horton and others, 1989) consist mostly of phyllitic metaclastic rocks (Mine Run Complex of Pavlides, 1989) that locally contain exotic blocks of metaplutonic, metavolcanic, metamafic, and metaultramafic rock types several meters and larger in size. These rocks occur to the east of the Mountain Run fault, the boundary between the Blue Ridge and Piedmont Provinces in this part of the central Appalachians (Pavlides, 1994). Burton and others (2015a) and Evans (2017) redefined lithostratigraphic units in this part of the Potomac terrane by replacing the fault-bounded Mine Run Complex units of Pavlides (1989) with (1) the informal Shores complex of Brown (1986) in the footwall of the Chopawamsic fault, which includes a narrow belt with mafic and ultramafic bodies bounded to the west by the Byrd Mill fault and the informal Byrd Mill formation of Burton and others (2014) in the footwall of the Byrd Mill fault; and (2) the informal Hardware formation of Evans (1984), located structurally beneath the Byrd Mill formation and in the hanging wall of the Mountain Run fault. In this schema, only rocks of the Shores complex between the Byrd Mill and Chopawamsic faults contain exotic mélange blocks of mafic and ultramafic rocks; Potomac terrane metaclastic rocks to the west are interpreted to be Laurentian slope-rise strata that were intruded by granitoid plugs, stocks, and small plutons.

Granodiorite of the approximately 444-436 million years old (Ma) Ellisville pluton (Hopkins, 1960; Pavlides and others, 1994; Hughes and others, 2013) intrudes both the Potomac terrane and the Chopawamsic Formation (fig. 2) and provides a temporal constraint for when the volcanic arc represented by the Chopawamsic Formation docked with Laurentia (Hughes and others, 2013). Other regional plutonic rocks of similar age include the Lahore, Green Springs, Carysbrook, and Columbia plutons.

The Chopawamsic Formation (Southwick and others, 1971) is a heterogeneous unit consisting of interlayered felsic, intermediate, and mafic metavolcanic and metasedimentary rocks of island-arc affinity (Pavlides, 1981). Rocks of this formation occur in separate eastern and western belts that are separated by Quantico Formation rocks in the core of the Quantico synclinorium (fig. 2). Rocks of felsic and intermediate composition (leucocratic felsic gneiss and biotite gneiss, schist, and rare quartzite) dominate the western belt, whereas rocks of mostly mafic composition (amphibolite) are interlayered with Ordovician-Silurian sheet-intrusive granitoids in the eastern belt. For this reason, Pavlides (1980) interpreted rocks in the eastern belt to be a separate unit he termed the Ta River Metamorphic Suite. Sparse altered ultramafic rocks (amphibole schist and talc-chlorite schist) are associated with amphibolite in the eastern belt. Granodioritic to tonalitic sheet intrusions and associated pegmatites in the eastern belt were interpreted as the Carboniferous (325-300 Ma) Falmouth Intrusive Suite (Pavlides, 1980) by Pavlides and others (1982b) from concordant U-Pb zircon ages and two rubidiumstrontium (Rb-Sr) whole-rock isochrons. Mixon and others (2000) named one of these intrusive bodies near Lake Anna as the Elk Creek pluton, with no supporting geochronologic data.

In the western belt, a through-going and nearly continuous amphibolite body near Contrary Creek (Mineral quadrangle, fig. 2) separates Chopawamsic Formation rocks into a lower section of felsic gneiss and biotite gneiss, and an upper section of mostly felsic meta-volcanic gneiss and schist. The top of this variably thick mafic unit, which has been the target zone for extensive iron, precious metal, and sulfide mining since the 1800s (for example, Luttrell, 1966; Pavlides and others, 1982a; Sauer, 1984), is interpreted as an unconformity. Elsewhere, rocks in the cores of regional synclines define major stratigraphic horizons. Ferruginous quartzite, metasiltstone, and graphitic schist in the Long Island and subsidiary synclines cap the western belt of the Chopawamsic Formation, whereas in the eastern belt a syncline of Chopawamsic Formation felsic gneiss flanks a larger anticlinorium cored by amphibolite and sheet intrusions (fig. 2).

Coler and others (2000) reported a thermal ionization mass spectrometry (TIMS) U-Pb age of 471.4 $\pm 1.3 \mathrm{Ma}$ for a sample of Chopawamsic Formation rhyolite from near Palmyra, Virginia (fig. 2). Coler and others (2000) also dated a nearby metabasalt in the western belt of felsic gneiss (see their fig. 2, p. 365) at 470.0+1.3/-1.5 Ma and concluded that the Ta River Metamorphic Suite is equivalent in age and correlative with the Chopawamsic Formation. Bailey and others (2005) mapped Chopawamsic Formation around the polydeformed south terminus of the Quantico synclinorium (fig. 2) near Columbia, Virginia, just north of the James River, but Pavlides and others (1994) considered the Ta River Metamorphic Suite to be Cambrian in age. Hughes and others $(2014 a, b)$ reported a TIMS U-Pb zircon age of approximately $468 \mathrm{Ma}$ for metavolcanic rocks (metafelsite) of the Chopawamsic Formation, and a strongly unimodal age of approximately $467 \mathrm{Ma}$ for detrital zircons from interlayered metasedimentary rocks. Hughes and others (2014a) concluded that the Chopawamsic Formation metasedimentary rocks were mostly recycled from its syndepositional volcanic pile, but they did record a scattering of Cambrian (approximately 537-510 Ma), Neoproterozoic (approximately 640-575 Ma) and Mesoproterozoic (approximately 1.17-1.01 billion years old [Ga]) detrital zircons. Horton and others (2010) reported a younger SHRIMP-RG $\mathrm{U}-\mathrm{Pb}$ zircon age of approximately $453 \mathrm{Ma}$ for Chopawamsic Formation metavolcanic rocks in northern Virginia.

The Quantico Formation (Pavlides, 1980) consists predominantly of garnet-mica schist, with local occurrences of 


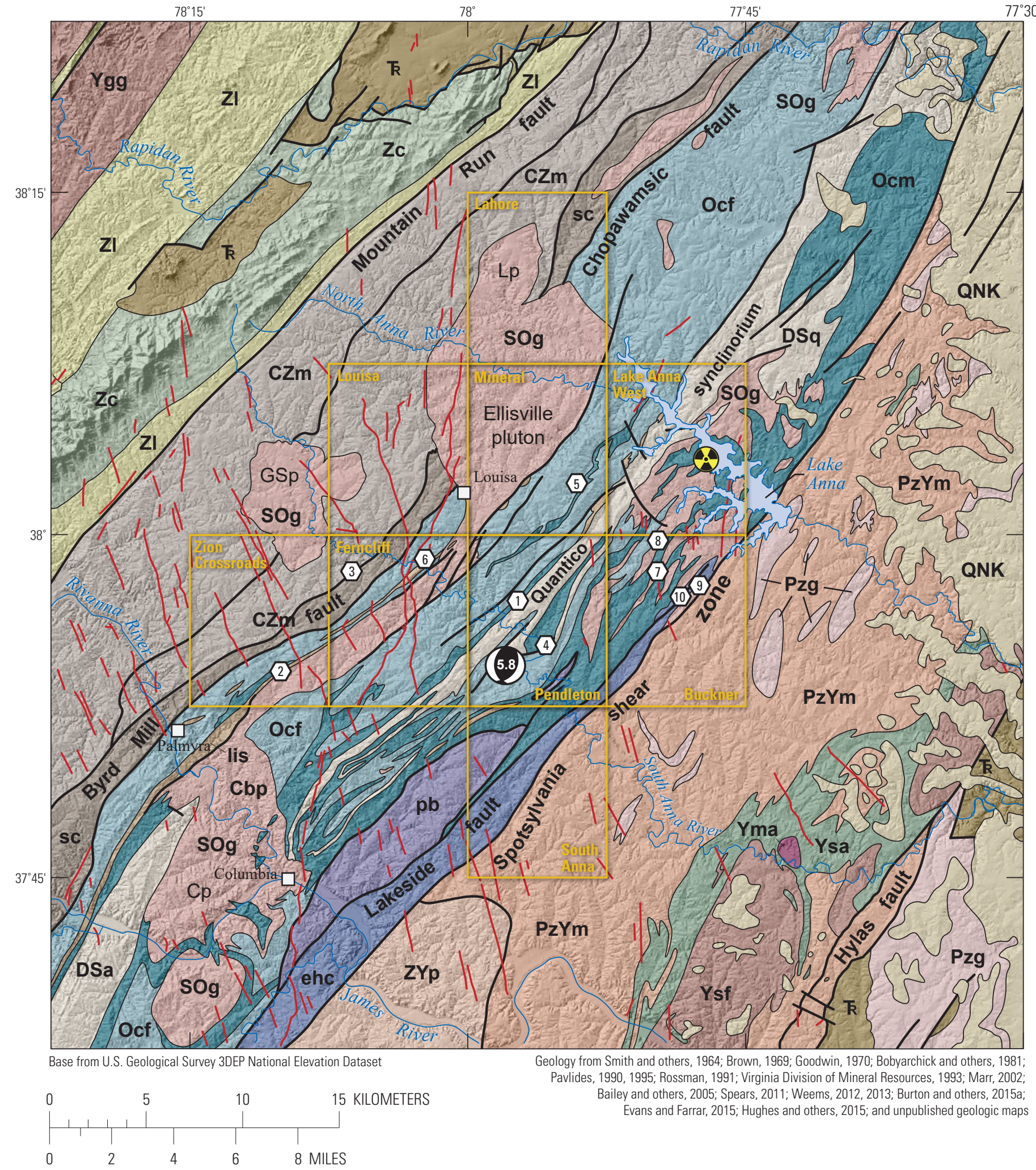




\section{EXPLANATION}

\begin{tabular}{|c|c|}
\hline QNK & Coastal Plain sediments \\
\hline$\lambda$ & Mesozoic diabase dikes \\
\hline $\mathbf{R}$ & Mesozoic sedimentary basins \\
\hline $\mathrm{Pzg}$ & Alleghanian granitoids \\
\hline $\mathrm{pb}$ & Pegmatite belt rocks \\
\hline ehc & $\begin{array}{l}\text { Rocks of the Elk Hill Complex } \\
\text { (including paragneiss) }\end{array}$ \\
\hline $\mathrm{DSq}$ & Successor basin synclinoriums \\
\hline DSa & $\mathrm{DSq}$-Quantico Formation \\
\hline & DSa_Arvonia Formation \\
\hline $\mathrm{sOg}$ & Silurian-Ordovician granitoids \\
\hline lis & $\begin{array}{l}\text { Sedimentary rocks of the Long Island } \\
\text { syncline }\end{array}$ \\
\hline & Chopawamsic Formation \\
\hline $0 \mathrm{~cm}$ & Ocf-Felsic \\
\hline & OCm-Mafic \\
\hline sc & $\begin{array}{l}\text { Melange-Rocks of the Shores complex } \\
\text { and Byrd Mill formation }\end{array}$ \\
\hline $\mathrm{eZm}$ & $\begin{array}{l}\text { Laurentian slope-rise rocks of the } \\
\text { Potomac terrane (Mine Run Complex) }\end{array}$ \\
\hline PzYm & Maidens Gneiss of the Goochland terrane \\
\hline $\mathrm{ZYp}$ & Carolina terrane rocks \\
\hline
\end{tabular}

\begin{tabular}{|c|c|c|}
\hline \multirow{5}{*}{$\begin{array}{l}\mathrm{Zc} \\
\mathrm{ZI} \\
\mathrm{Ygg} \\
\end{array}$} & \multicolumn{2}{|c|}{ Blue Ridge rocks } \\
\hline & \multirow{2}{*}{\multicolumn{2}{|c|}{ Zc-Catoctin Formation }} \\
\hline & & \\
\hline & \multicolumn{2}{|c|}{ Zl-Lynchburg Formation } \\
\hline & \multicolumn{2}{|c|}{ Ygg-Mesoproterozoic basement } \\
\hline la & \multicolumn{2}{|c|}{ Goochland terrane rocks } \\
\hline $\begin{array}{l}\text { Ysa } \\
\text { Ysf }\end{array}$ & \multicolumn{2}{|c|}{ Yma-Montpelier Anorthosite } \\
\hline & \multicolumn{2}{|c|}{ Ysa_-Sabot Amphibolite } \\
\hline & \multicolumn{2}{|c|}{ Ysf_-State Farm Gneiss } \\
\hline & \multicolumn{2}{|c|}{ North Anna Power Plant } \\
\hline & \multicolumn{2}{|c|}{$\begin{array}{l}\text { Epicenter of magnitude } 5.8 \text { Mineral } \\
\text { Virginia earthquake }\end{array}$} \\
\hline$\underset{\text { Palmyra }}{\square}$ & \multicolumn{2}{|c|}{ Location of city or town and na } \\
\hline (1) & \multicolumn{2}{|c|}{$\begin{array}{l}\text { Sample site discussed in text- } \\
\text { Number is site identifier }\end{array}$} \\
\hline & $\begin{array}{c}\text { Site } \\
\text { identifier }\end{array}$ & Sample site \\
\hline & 1 & White Walnut \\
\hline & 2 & ZXR-1 \\
\hline & 3 & BBF-220 \\
\hline & 4 & M16-05-31A \\
\hline & 5 & MN-183 \\
\hline & 6 & BBF-019 \\
\hline & 7 & BK234 \\
\hline & 8 & BK650 \\
\hline & 9 & BK544 \\
\hline & 10 & BK601 \\
\hline
\end{tabular}

Figure 2. (Left) Regional bedrock geology map of the central Virginia Piedmont. Quadrangles mapped in detail and referenced in the text are outlined with red boxes. Cp, Columbia pluton; Cbp, Carysbrook pluton; GSp, Green Springs pluton; Lp, Lahore pluton. Sample localities discussed in text and listed in table 1. Original 1/3 arc-second resolution elevation data from the U.S. Geological Survey 3DEP National Elevation Dataset available at https://viewer.nationalmap.gov. Base map image constructed from these data using Global Mapper version 18.1.0. 
graphite, chloritoid, and staurolite. These rocks occur in the core of the Quantico synclinorium (Mixon and others, 2000; fig. 2), which extends nearly 140 kilometers from the Occoquan River, in Fairfax County, northern Virginia, nearly to the James River in Fluvanna County, central Virginia. Preserved faunal assemblages (Watson and Powell, 1911; Pavlides and others, 1980) point to a latest Ordovician to Devonian age for the unit. Along the James River, the Arvonia Formation (Watson and Powell, 1911) is biostratigraphically equivalent to the Quantico Formation (Kolata and Pavlides, 1986), and demonstrably overlies Columbia Granite (459.1 $17.3 \mathrm{Ma}$; Sinha and others, 2012) along a regional unconformity (Smith and others, 1964; Glover, 1989; Bailey and others, 2005). The Quantico Formation, and the equivalent Arvonia Formation to the southwest (fig. 2), contain detrital zircons ranging in age from $430 \mathrm{Ma}$ (Hughes and others, 2014a) to as young as $390 \mathrm{Ma}$ (Bailey and others, 2008); these units have been interpreted as postorogenic successor basin deposits (for example, Hughes and others, 2015). Similar rocks occur in a syncline west of the Quantico and Arvonia Formations (Long Island syncline of Smith and others, 1964), but Bailey and others (2005) assigned these rocks (graphitic schist, metagraywacke, and interlayered metarhyolite) to the Chopawamsic Formation.

East of the Chopawamsic Formation are metamorphic rocks of the Elk Hill Complex (Taber, 1913), which include biotite-muscovite gneiss and strongly layered granitic gneiss with layers and boudins of amphibolite (Spears and others, 2004). The Lakeside fault (Bourland and others, 1979; Brown, 1986; Spears and others, 2004, 2013; Spears, 2011) separates the Chopawamsic Formation from the Elk Hill Complex. Lakeside fault exposures reveal high-grade (amphibolite facies) ductile-deformed rocks with retrograde mineral assemblages and $\mathrm{S}-\mathrm{C}$ mylonitic fabrics in a variably thick zone, and brittle-deformed silicified cataclasite that is interpreted to represent Mesozoic overprinting of the Paleozoic structure (Spears and others, 2004). At the north terminus of the Elk Hill Complex near Lake Anna (fig. 2), biotite-muscovite migmatitic paragneiss structurally overlies the Chopawamsic Formation along a premetamorphic fault or an overturned unconformity, and S-C mylonitic rocks of the Lakeside fault terminate in the core of a map-scale fold of paragneiss.

Roig and others (2017) dated granitic gneiss at the type locality of the Elk Hill Complex using isotope dilution (ID)TIMS (U-Pb zircon) at $331 \pm 10 \mathrm{Ma}$. Granitic gneisses from the pegmatite belt adjacent to the west (Taber, 1913; fig. 2) were also dated; granitic gneisses from two localities yielded IDTIMS U-Pb zircon ages of $427.9 \pm 4.3 \mathrm{Ma}$ and $423.7 \pm 1.5 \mathrm{Ma}$, and monazite from one of these localities yielded an age of 325.2 $1.3 \mathrm{Ma}$ (Roig and others, 2017). The Elk Hill Complex is bordered on the east by the Maidens Gneiss of the Goochland terrane along the Spotsylvania fault zone (Bailey and others, 2004; Spears and others, 2004).
Metamorphic grade increases from west to east across the transect, but argon (Ar) geochronology indicates that the gradient is likely a result of several Paleozoic events (Burton and others, 2015b; McAleer and others, 2017). In the Potomac terrane and westernmost edge of the Chopawamsic terrane, primary bedding is preserved at greenschist-facies; published preliminary ${ }^{40} \mathrm{Ar} /{ }^{39} \mathrm{Ar}$ plateau and correlation ages indicate Late Ordovician metamorphism (Burton and others, 2015b). Eastward, Quantico Formation and underlying Chopawamsic Formation rocks are deformed by multiple ductile foliations and brittle cleavage and metamorphosed to upper greenschistto amphibolite-facies (kyanite zone); published preliminary data are indicative of cooling from a tectonothermal event during the Alleghanian orogeny (Burton and others, 2015b). Amphibolite and biotite-granitoid sheet intrusions east of the Quantico synclinorium are also metamorphosed at upper greenschist- to amphibolite-facies, and highly deformed, but compositions do not allow isograds to be easily traced. Biotite-muscovite paragneiss preserves migmatitic textures that suggest partial melting.

\section{Sample Descriptions}

Detailed 1:24,000-scale geologic mapping across nine 7.5-minute quadrangles (fig. 2) identified the base of the Quantico Formation, refined the stratigraphy within the Chopawamsic Formation, and delineated a broad belt of granodioritic to tonalitic sheet intrusions in the eastern belt of the Chopawamsic Formation. Additionally, mapping confirmed the presence of the Elk Hill Complex, distinct from the eastern belt of Chopawamsic Formation belt of rocks. The confirmed and revised field relations allowed us to pinpoint sampling localities (fig. 2).

We collected three samples of metasedimentary rocks for LA-ICP-MS U-Pb detrital zircon geochronology and seven samples of metaigneous rocks for SHRIMP-RG U-Pb zircon crystallization geochronology (table 1). To determine a maximum depositional age of the Quantico Formation, a sample of quartzite (sample White Walnut) from the base of the formation was collected for LA-ICP-MS analysis, and a sample of quartz phenocryst-bearing felsic gneiss (sample M16-05-31A; figure 3A) was collected from near the base of the formation for SHRIMP-RG analysis. In addition, a sample of thinly bedded and cleaved metasiltstone in the core of the Long Island syncline (sample ZXR-1) was collected for LAICP-MS analysis to resolve the maximum depositional age of those rocks. A sample of fine-grained, well-foliated muscovitebiotite-chlorite-quartz schist (sample BBF-220) from the informal Byrd Mill formation (Shores complex, Potomac terrane) was collected to provide provenance data for comparison with previously published detrital zircon geochronology from the Potomac terrane (for example, Hughes and others, 2014a). 
Table 1. Summary of sample locations, dating methods, and age results of this study.

[Map locations shown in figure 2. Datum is World Geodetic System of 1984. dd, decimal degrees; LA-ICP-MS, laser ablation inductively-coupled plasma-mass spectrometer; SHRIMP-RG, sensitive high-resolution ion microprobe-reverse geometry; USGS, U.S. Geological Survey; Ma, million years]

\begin{tabular}{ccccccc}
\hline $\begin{array}{c}\text { Sample } \\
\text { identifier }\end{array}$ & $\begin{array}{c}\text { Sample } \\
\text { location }\end{array}$ & Unit & $\begin{array}{c}\text { Latitude } \\
\text { (dd) }\end{array}$ & $\begin{array}{c}\text { Longitude } \\
\text { (dd) }\end{array}$ & $\begin{array}{c}\text { USGS } \\
\text { quadrangle }\end{array}$ & Method \\
\hline White Walnut & $1 \quad \begin{array}{c}\text { Quantico Formation } \\
\text { quartzite }\end{array}$ & 37.95006 & 77.95361 & Pendleton & $\begin{array}{c}\text { LA-ICP-MS U-Pb } \\
\text { detrital zircon }\end{array}$ & $\begin{array}{c}\text { Youngest grain } \\
427 \pm 6 \mathrm{Ma}\end{array}$ \\
& & & &
\end{tabular}

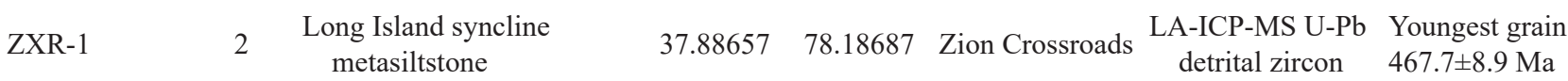

\begin{tabular}{|c|c|c|c|c|c|c|}
\hline BBF-220 & 3 & $\begin{array}{l}\text { Byrd Mill formation } \\
\text { (Potomac terrane) }\end{array}$ & 37.97501 & 78.0944 & Ferncliff & $\begin{array}{cl}\text { LA-ICP-MS U-Pb } & \text { Youngest grain } \\
\text { detrital zircon } & 971 \mathrm{Ma}\end{array}$ \\
\hline
\end{tabular}

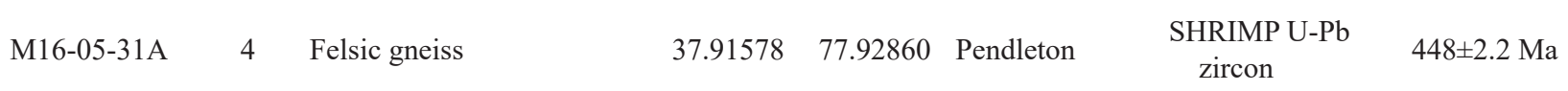

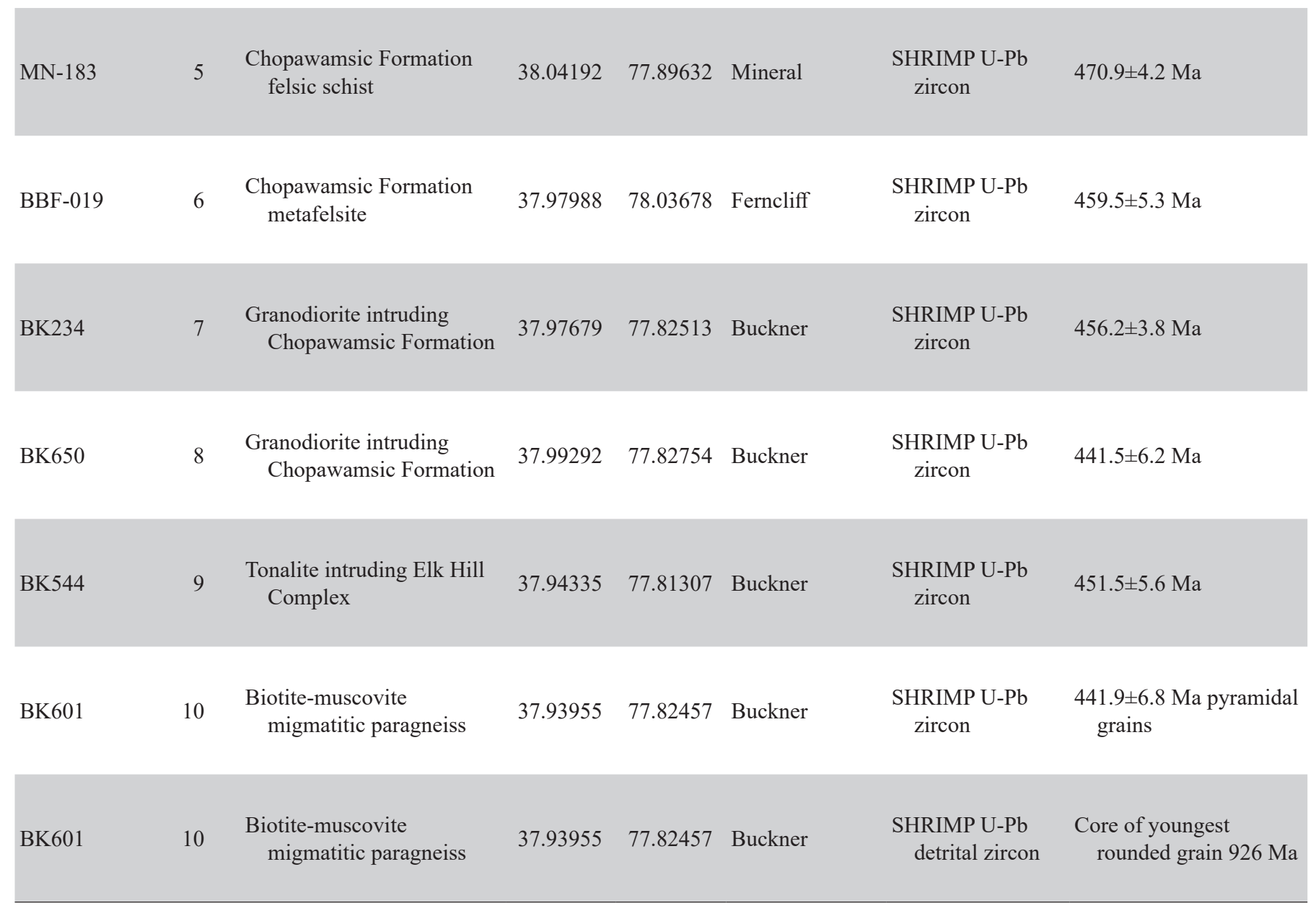



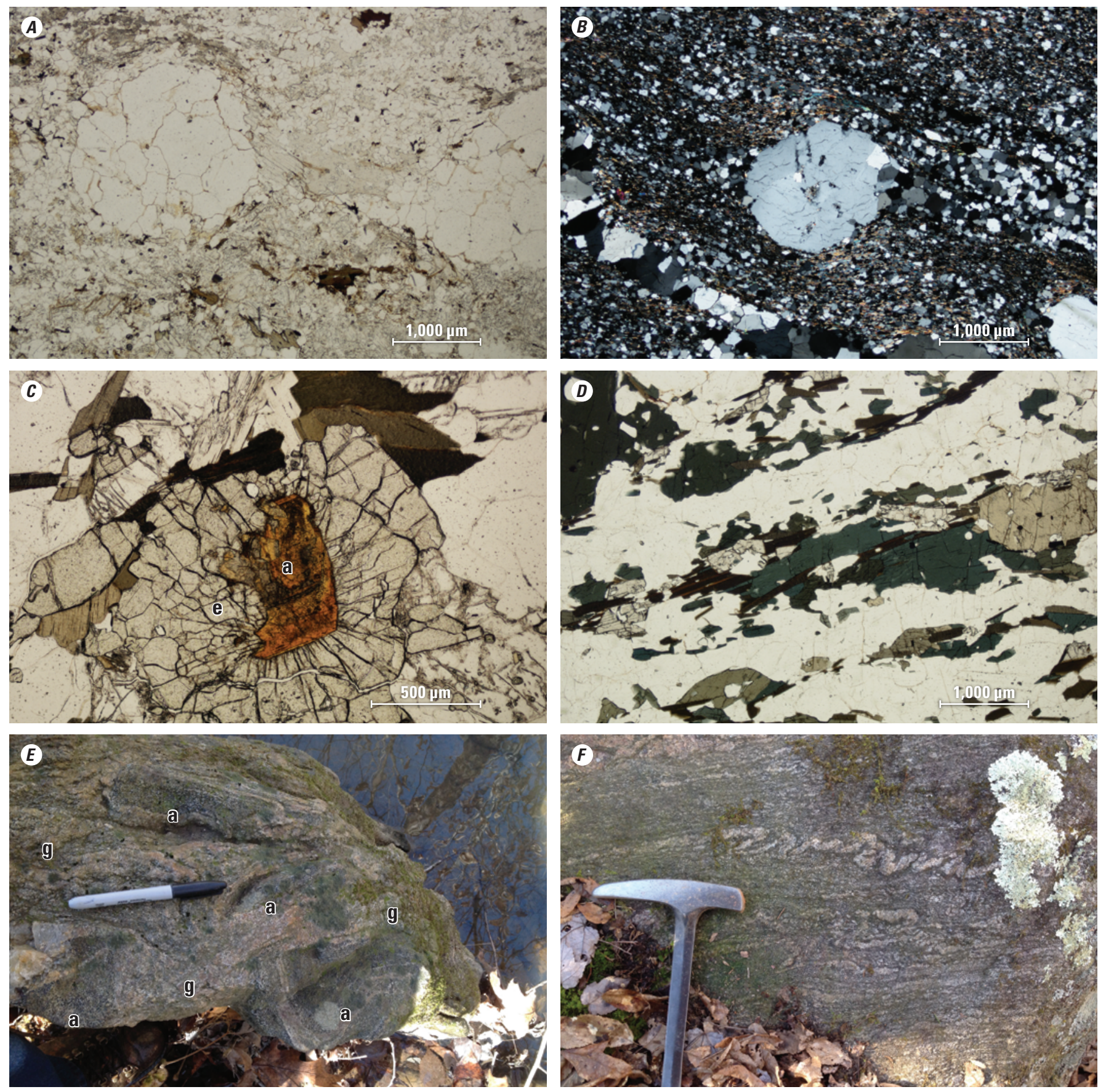

Figure 3. Photographs of rocks and structures from the central Virginia Piedmont. $A$, Photomicrograph of monocrystalline quartz phenocryst (porphyroclast) in felsic gneiss (sample M16-05-31A) from near the base of the Quantico Formation, plane-polarized light, 2x magnification. $B$, Photomicrograph of monocrystalline quartz phenocryst (porphyroclast) with deformation tails of fine-grained quartz from sample MN-183, crossed-polarized light, 2x magnification. C, Photomicrograph of magmatic epidote (e) cored by allanite (a) from metagranodiorite (sample BK650), plane-polarized light, 5x magnification. $D$, Photomicrograph of bluish-green amphibole in Elk Hill Complex tonalitic gneiss from sample BK544, plane-polarized light, 2x magnification. E, An outcrop of layered amphibolite xenoliths (a) in strongly foliated approximately 452 million year old hornblende-biotite metagranodiorite $(\mathrm{g})$ at location of sample BK544. Marker is 13.6 centimeters $(\mathrm{cm})$ (5.3 inches [in.]) long, for scale. F, An outcrop of biotite-muscovite migmatitic paragneiss at the north terminus of the Elk Hill Complex on the Buckner 7.5-minute quadrangle (fig. 2); hammerhead, approximately $17 \mathrm{~cm}(6.7 \mathrm{in}$.) long, for scale. $\mu \mathrm{m}$, micrometers. 
To establish stratigraphic succession within the Chopawamsic Formation based on relative stratigraphic relations from detailed mapping, two samples were collected from near the top and the bottom of the formation, respectively. Felsic schist (sample MN-183) occurs stratigraphically approximately 280 meters below a regional unconformity within the Chopawamsic Formation that was recognized through mineral exploration drilling (Sauer, 1984). This rock is multiply deformed and preserves both millimeter-thick isoclinally folded bands of coarser- and finer-grained quartz and feldspar, and penetrative axial-planar foliation defined by aligned muscovite. Significantly larger monocrystalline quartz phenocrysts are mantled by asymmetrical strain shadows composed of fine-grained recrystallized quartz (fig. 3B). Metafelsite (sample BBF-019) occurs stratigraphically beneath ferruginous quartzite in the core of a tight syncline that is along strike to the northeast from the Long Island syncline. The metafelsite is light gray and fine-grained, and contains relict phenocrysts of quartz and plagioclase, as well as porphyroblasts of biotite, in a matrix of fine-grained quartz, plagioclase, and potassium feldspar. A schistosity defined by fine-grained muscovite flattens or rotates the phenocrysts and biotite.

Four samples were collected for SHRIMP-RG analysis to determine the timing of deformation in the Chopawamsic Formation east of the Quantico synclinorium and the Elk Hill Complex. Two of these samples were collected from strongly foliated hornblende-biotite granodioritic and tonalitic sheet intrusions that are interlayered at map-scale with predominantly amphibolite in the eastern belt of the Chopawamsic Formation. The first sample (BK234) is a strongly foliated metagranodiorite that contains quartz, plagioclase, myrmekite, and potassium feldspar; the second sample (BK650) is a strongly foliated metagranodiorite that contains quartz and plagioclase, with potassium feldspar porphyroclasts (interpreted to be relict phenocrysts) as much as 1 centimeter in length. Biotite and epidote compose the mafic mineral phases in both samples, and muscovite is an accessory metamorphic phase (garnet is also an accessory phase in sample BK234). Coarse epidote is commonly cored by allanite and is interpreted to be magmatic (fig. 3C). Aligned biotite defines the dominant foliation in outcrop and samples, with a weak secondary foliation defined by aligned muscovite at a slight angle. Outcrops at the BK234 sample location contain several decimeterthick muscovite-bearing pegmatite dikes that are concordant with the dominant foliation. The third sample (BK544) was collected from strongly foliated hornblende-biotite tonalitic gneiss that contains xenoliths of amphibolite within the Elk Hill Complex between the Lakeside and Spotsylvania faults. Mafic phases include both bluish-green amphibole (fig. $3 D$ ) and biotite. Epidote typically has an aspect ratio of $3: 1$, is elongate in the plane of the foliation, and is interpreted to be metamorphic in origin. Nearby granodioritic gneiss contains sparse garnet. Centimeter-thick bands of elongated quartz and feldspar, alternating with centimeter-thick bands of biotite-amphibole constitute the dominant foliation, but a weak oblique secondary foliation of muscovite is preserved in nearby granodioritic gneiss. In outcrop, tonalitic and granodioritic gneisses contain decimeter- to meter-scale xenoliths of amphibolite, which preserve an earlier foliation that is oblique to foliation in the enclosing metaigneous rock (fig. $3 E$ ). The fourth sample (BK601) was collected from biotite-muscovite migmatitic paragneiss at the north terminus of the Elk Hill Complex (fig. 2). It consists of quartz, plagioclase, muscovite, and biotite, with epidote, garnet, and apatite. In outcrop, biotite-muscovite gneiss is polydeformed; centimeter-thick layers and stringers of quartz and feldspar define migmatitic layering (fig. $3 F$ ), which is tight to isoclinally folded. Aligned biotite and muscovite define penetrative foliation that is axial-planar to isoclinal folds. Both migmatitic layers and phyllosilicate-rich foliation planes are broadly to tightly folded in several orientations.

\section{Analytical Methods}

LA-ICP-MS U-Pb detrital zircon analysis was conducted at the U.S. Geological Survey (USGS) Laser Ablation-ICPMS Isotope Laboratory, housed at the Geology, Geophysics, and Geochemistry Science Center in Denver, Colorado. Zircon was ablated with a Photon Machines Excite 193 nanometer argon fluoride (ArF) excimer laser in spot mode. The laser spot sizes for zircon were $\sim 25$ micrometers $(\mu \mathrm{m})$; pit depths are typically less than $20 \mu \mathrm{m}$. Analytical procedures are described in appendix 1; data are presented in table 2 (available at https://doi.org/10.3133/pp1861) and in standard graphical form in figure $4 .{ }^{206} \mathrm{~Pb} /{ }^{238} \mathrm{U}$ ages are reported for zircons younger than approximately $1,300 \mathrm{Ma}$ and ${ }^{207} \mathrm{~Pb} /{ }^{206} \mathrm{~Pb}$ ages are used for zircons older than 1,300 Ma following the recommendations of Gehrels (2012). Zircon grains from igneous samples and from biotite-muscovite migmatitic paragneiss were analyzed during two sessions in 2016 and 2017 by secondary ionization mass spectrometry on the USGS/ Stanford SHRIMP-RG, using a spot diameter of $\sim 20 \mu \mathrm{m}$. Samples BK234, BK544, BK650, and M16-05-31A were analyzed in 2016, and samples BBF-019, MN183, and BK601 were analyzed in 2017. Analytical procedures are described in appendix 2. Weighted average ages determined from the ${ }^{206} \mathrm{~Pb} /{ }^{238} \mathrm{U}$ spot ages are reported in table 1 and the uncertainty is reported at $2 \sigma$. Isotopic data for individual spots are reported in table 2 and are presented in graphical form in figures 5-8. For spot ages older than $1,300 \mathrm{Ma}$, the ${ }^{207} \mathrm{~Pb} /{ }^{206} \mathrm{~Pb}$ age is plotted (Gehrels, 2012). Samples analyzed with the SHRIMP-RG were imaged with scanning electron microscopy-cathodoluminescence (CL), a back-scatter electron (BSE) detector, and ultraviolet light (UV). 

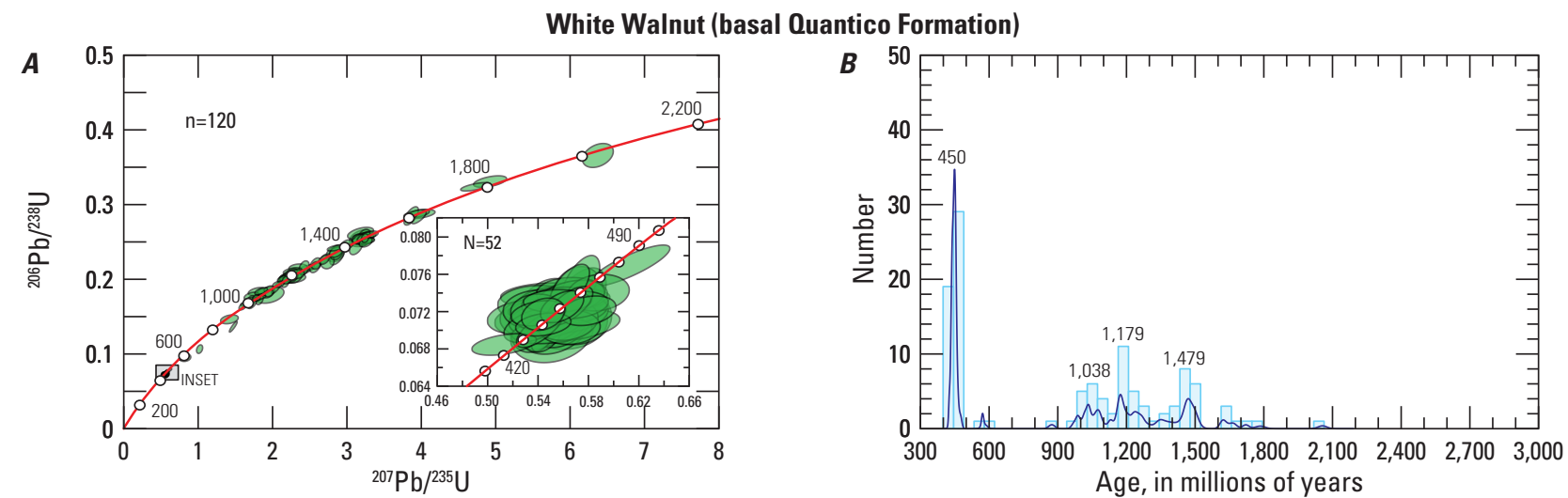

ZXR-1 (Long Island syncline rocks)
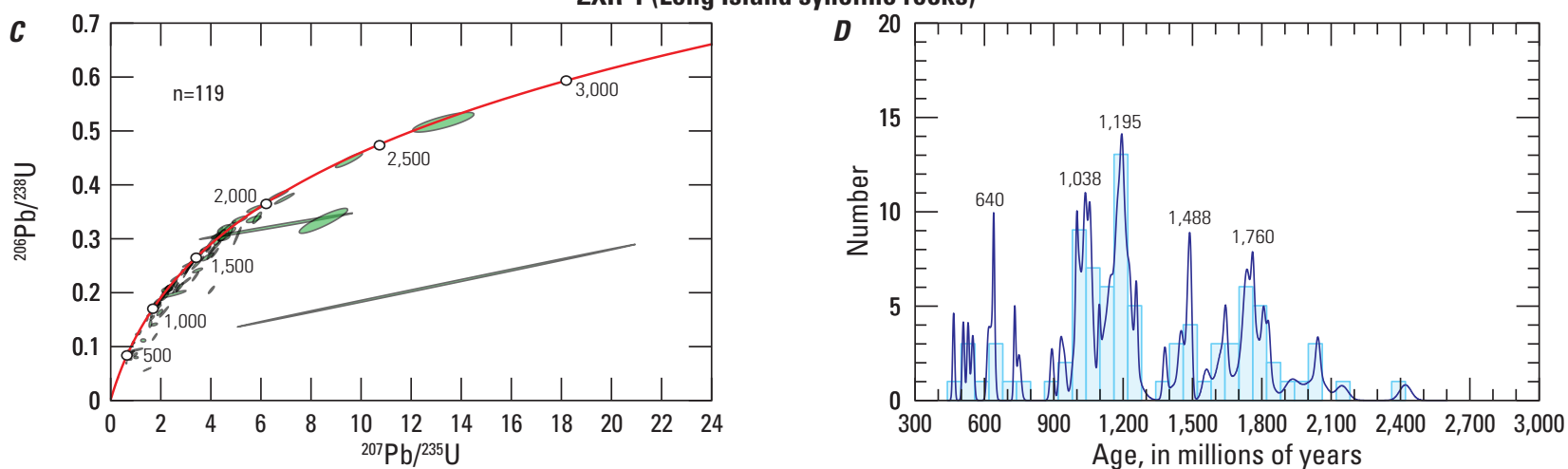

BBF-220 (Byrd Mill formation)
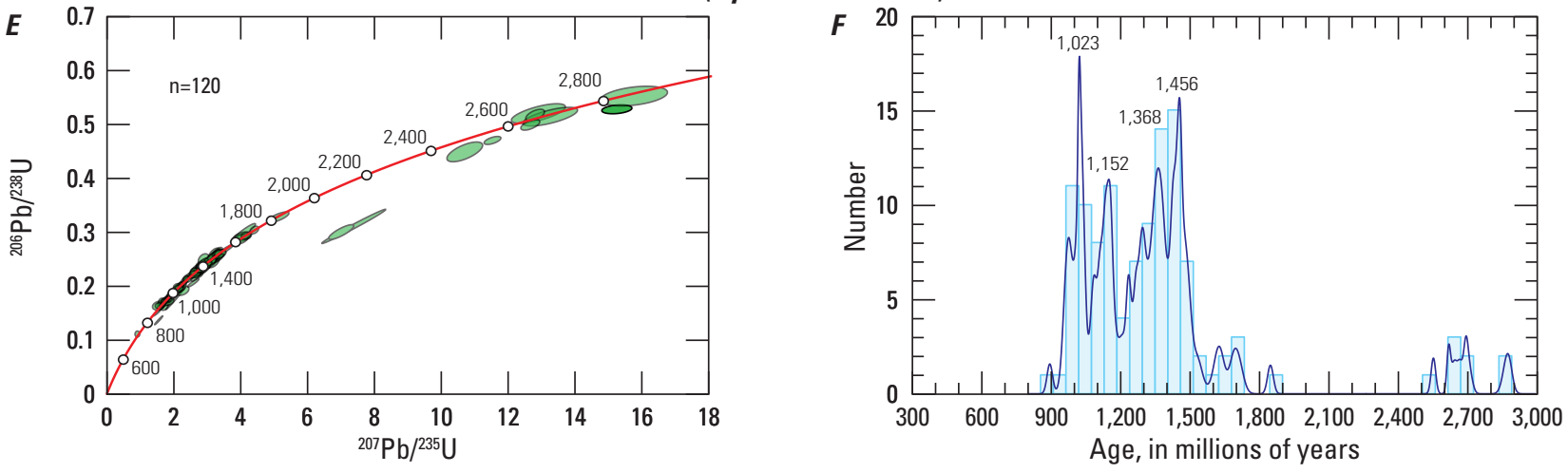

BK601 (biotite-muscovite migmatitic paragneiss)
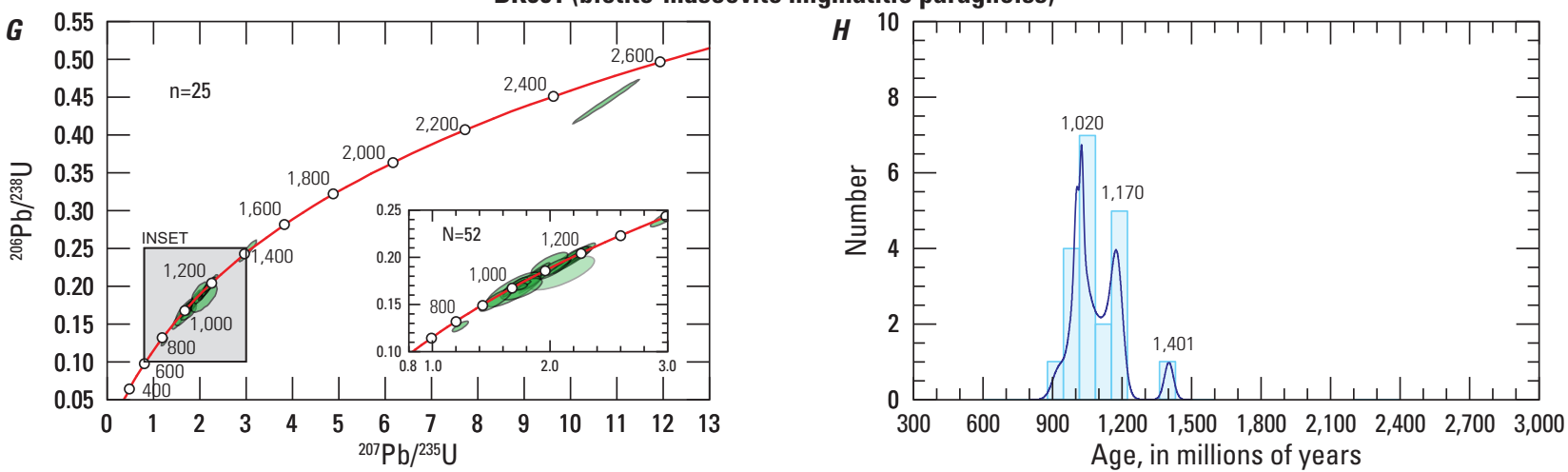

Figure 4. Plots of laser ablation-inductively coupled plasma-mass spectrometry detrital zircon data (samples White Walnut, ZXR-1, and BBF-220) and sensitive high-resolution ion microprobe detrital zircon data (sample BK601) from central Virginia Piedmont samples collected during this study. Concordia and relative probability plots from $A$ and $B$, basal quartzite of the Quantico Formation (sample White Walnut); $C$ and $D$, Long Island syncline metasiltstone (sample ZXR-1); $E$ and $F$, Byrd Mill formation mica-quartz schist (sample BBF-220); and $G$ and $H$, rounded zircon cores from migmatitic paragneiss (sample BK601). 


\section{Results}

LA-ICP-MS analysis of quartzite (sample White Walnut) from the base of the Quantico Formation revealed the youngest grain in the sample to be $427 \pm 6 \mathrm{Ma}$, but this age may just be the youngest part of the normal distribution of a peak age population at approximately $450 \mathrm{Ma}$ (fig. $4 A$ ). Other populations are at 1,479 Ma, 1,179 Ma, and 1,038 Ma (n=115). Metasiltstone from the Long Island syncline (sample ZXR-1) contains a few grains with ages between approximately $570 \mathrm{Ma}$ and $470 \mathrm{Ma}$; the youngest grain in this sample is

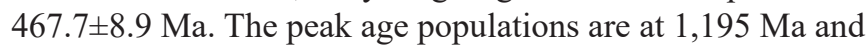
$1,038 \mathrm{Ma}$ but are broadly distributed to approximately $2 \mathrm{Ga}$ (fig. 4B), including population peaks at 1,760 Ma, 1,488 Ma, $1,038 \mathrm{Ma}$, and $640 \mathrm{Ma}(\mathrm{n}=89)$. For comparison, schist (sample BBF-220) from the Byrd Mill formation (Potomac terrane) yielded a peak age population at 1,023 Ma (fig. 4C), with other populations at 1,456 Ma, 1,368 Ma, 1,152 Ma and $971 \mathrm{Ma}$ $(\mathrm{n}=115)$. There were no detrital zircons younger than approximately $900 \mathrm{Ma}$, therefore a maximum depositional age is not well constrained by the Byrd Mill formation sample.

Zircon grains from felsic gneiss (sample M16-05-31A) from near the base of the Quantico Formation exhibit oscillatory zoning in CL and BSE images (fig. $5 A$ ). No texturally distinct rims are present. Analyses yielded a ${ }^{206} \mathrm{~Pb} /{ }^{238} \mathrm{U}$ weighted average age of $448.1 \pm 2.2 \mathrm{Ma}$ (fig. $5 A$ ).

Zircon grains from two samples (MN-183 and BBF-019) from different stratigraphic intervals in the Chopawamsic Formation west of the Quantico synclinorium have cores that exhibit oscillatory zoning in CL and BSE and 1-2- $\mu \mathrm{m}$-thick patchy and irregular overgrowths. In sample $\mathrm{MN}-183$ the overgrowths are zircon (fig. 5B), and in sample BBF-019 they are xenotime (fig. 5 C). Analyses of grain cores in sample MN-183 yielded a weighted mean age of $471.0 \pm 4.2 \mathrm{Ma}$ (fig. $5 B$ ), and BBF-019 yielded a weighted mean age of $459.5 \pm 5.3 \mathrm{Ma}$ (fig. 5C).

Zircon grains from two samples (BK234 and BK650) from biotite granodioritic sheet intrusions from the eastern portion of the Chopawamsic Formation have cores that exhibit oscillatory zoning in CL and BSE, dark mantles, and narrow rims that embay the zoning and are relatively bright in CL. SHRIMP-RG analyses of grain cores from sample BK234 yielded a ${ }^{206} \mathrm{~Pb} /{ }^{238} \mathrm{U}$ weighted average age of $456.2 \pm 3.8 \mathrm{Ma}$ (fig. $6 \mathrm{~A}$ ) and analyses of grain cores from sample BK650 yielded a ${ }^{206} \mathrm{~Pb} /{ }^{238} \mathrm{U}$ weighted average age of $441.5 \pm 6.2 \mathrm{Ma}$ (fig. $6 B$ ). In both samples the CL-bright rims were typically too narrow to analyze. However, a single spot analysis from a grain rim in each sample yielded anomalously low thorium $(\mathrm{Th})$ concentrations and high $\mathrm{U} / \mathrm{Th}$ ratios, and ages that suggest the narrow rims are of Alleghanian metamorphic origin (sample BK234: $306 \pm 6 \mathrm{Ma}, \mathrm{U}=79$ parts per million [ppm], Th=0 ppm; sample BK650: $277 \pm 27 \mathrm{Ma}, \mathrm{U}=4 \mathrm{ppm}$, $\mathrm{Th}=0 \mathrm{ppm}$ ). Three inherited cores of $\sim 1 \mathrm{Ga}$ were also analyzed in sample BK234. Diffuse CL zoning, low uranium and thorium concentrations, and U/Th ratios of less than 5 chemically distinguish these inherited cores.

Zircon grains from tonalitic gneiss of the Elk Hill Complex (sample BK544) have cores that exhibit broad sector zoning in $\mathrm{CL}$ and relatively bright rims that embay the zoning. SHRIMP-RG analyses of cores yielded a ${ }^{206} \mathrm{~Pb} /{ }^{238} \mathrm{U}$ weighted average age of $451.5 \pm 5.6 \mathrm{Ma}$ (fig. $6 \mathrm{C}$ ). Four analyses of the thickest CL-bright rims yielded anomalously low uranium (7-25 ppm) and thorium (0-1 ppm) concentrations and ages of $331 \pm 9 \mathrm{Ma}, 328 \pm 9 \mathrm{Ma}, 314 \pm 6 \mathrm{Ma}$, and $253 \pm 9 \mathrm{Ma}$. The textural and compositional results indicate the rims are metamorphic in origin and the $\mathrm{U} / \mathrm{Pb}$ ages suggest the rims are broadly Alleghanian in age.

Three morphologic populations of zircon were identified in migmatitic paragneiss at the north terminus of the Elk Hill Complex (sample BK601; figs. 2 and 7A): elongated pyramidal grains with aspect ratios of as much as 8:1 (fig. 7B), rounded zircons that appear to be detrital in origin (fig. $7 C$ ), and zircon aggregates composed of 2-8 elongate zircon grains (fig. 7C). Rounded and elongate grains were analyzed by SHRIMP-RG U-Pb geochronology methods (figs. $4 G$ and $H$, and 8). All rounded grains yielded Neoproterozoic or older ages consistent with a detrital origin for these grains and a sedimentary protolith for the gneiss (fig. $4 G$ and $H$ ). The youngest core of a rounded grain yielded an age of approximately $926 \mathrm{Ma}$; cores of other rounded grains yielded peak age populations of 1,170 Ma, 1,020 Ma, and approximately $1,000 \mathrm{Ma}$. One grain also yielded an age of $1,401 \mathrm{Ma}(\mathrm{n}=20$; fig. $4 G$ and $H$ ). A single, discordant Archean to Paleoproterozoic grain core was also present (fig. $7 B$ ). Elongate pyramidal grains were dark in CL and bright in BSE, and zoning patterns varied from oscillatory to patchy. Several grains also had rims that were brighter in CL and embayed the grain cores. Cores of elongated pyramidal grains yielded a mean age of 439.4 $\pm 7.3 \mathrm{Ma}$ (fig. $8 A$ ). Rims on the elongated grains yielded ages of $334 \pm 8 \mathrm{Ma}, 322 \pm 5 \mathrm{Ma}$, and $318 \pm 13 \mathrm{Ma}$ (fig. $8 A$ ). Both the cores and rims had $\mathrm{U} / \mathrm{Th}$ ratios greater than 20 (fig. $8 B$ ), but grain cores were typically richer in uranium $(>1,000 \mathrm{ppm})$. 


\section{A. M16-05-31A}
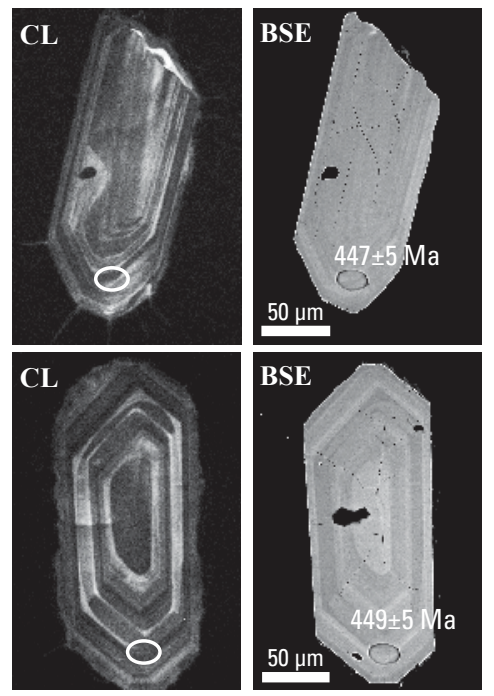

\section{B. $\mathrm{MN}-183$}

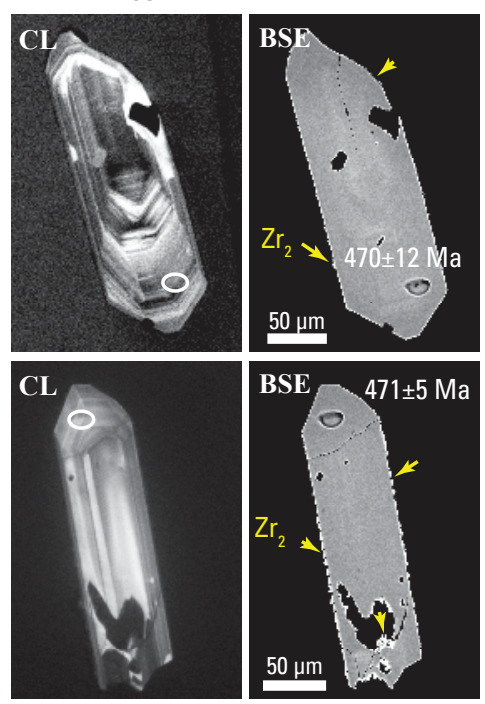

C. BBF-019

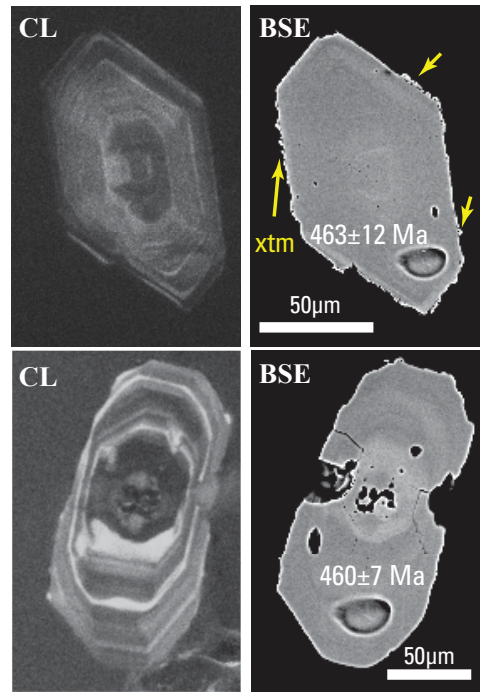

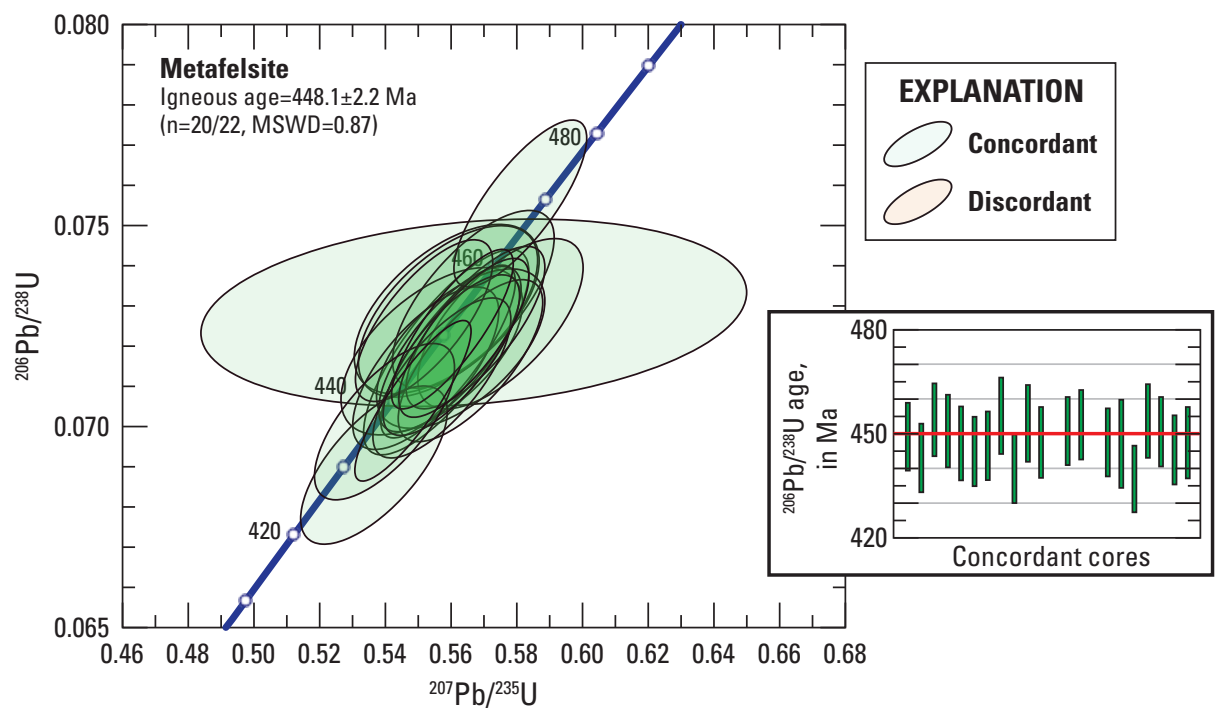
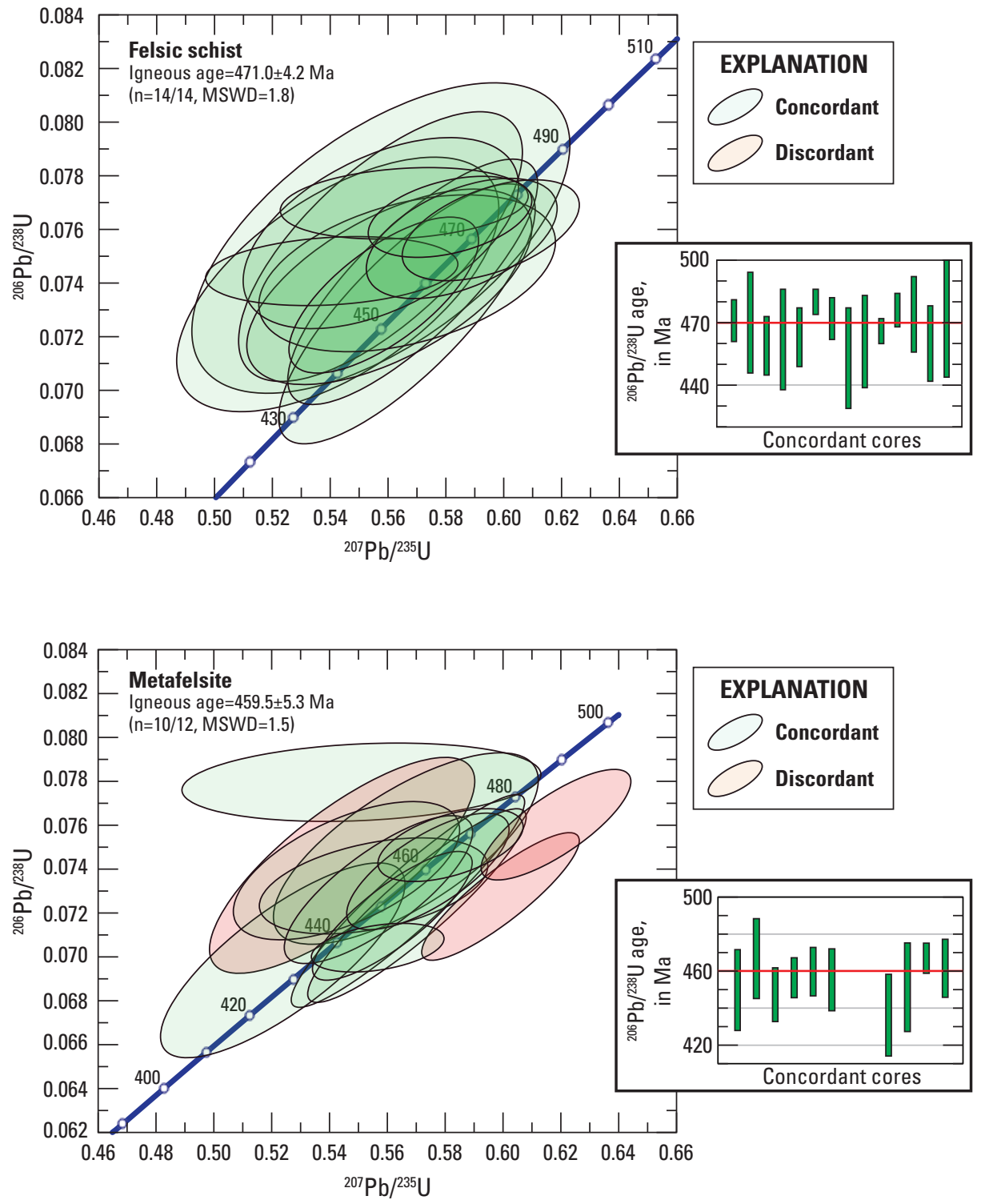
Figure 5. (Left) Scanning electron microscopy-back-scatter electron (BSE) detector and scanning electron microscopycathodoluminescence $(C L)$ images of representative zircon grains and plots of isotopic data from the samples analyzed on the Stanford/U.S. Geological Survey sensitive high-resolution ion microprobe-reverse geometry. All concordant (green) and discordant (red) analyses of grain cores are plotted on the concordia diagrams. Only concordant data are plotted on weighted mean diagrams (inset). Data for all analyses can be found in table 3. $A, C L$ and BSE images of prismatic zircon exhibiting oscillatory zoning in sample M16-05-31A (metafelsite near the base of the Quantico Formation). Concordia and weighted average diagrams are for igneous zircon cores from sample M16-05-31A; B, CL and BSE images of prismatic and elongate zircon exhibiting oscillatory zoning in sample MN-183 (quartz phenocryst-bearing felsic schist of the lower part of the Chopawamsic Formation). Overgrowths of irregular zircon $\left(\mathrm{Zr}_{2}\right)$ are present on grain margins. Concordia and weighted average diagrams are for igneous zircon cores from sample MN-183; C, CL and BSE images of prismatic zircon exhibiting oscillatory zoning in sample BBF-019 (metafelsite beneath ferruginous quartzite). Irregular overgrowths of xenotime (xtm) are present on most zircon grains. Concordia and weighted average diagrams are for igneous zircon cores from sample BBF-019. All plots are at 2-sigma; $M a$, million years old; MSWD, mean square of weighted deviates; $\mu \mathrm{m}$, micrometers. 


\section{A. BK234}
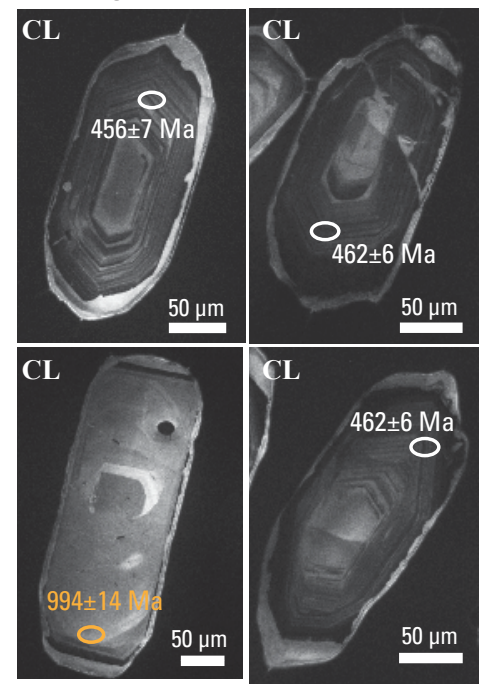

\section{B. BK650}
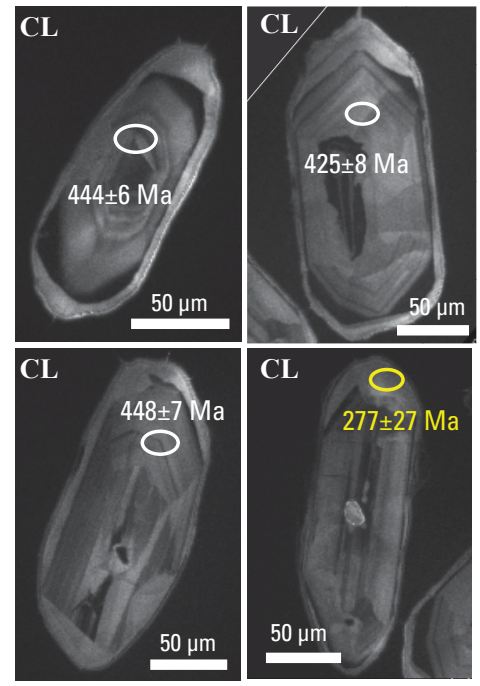

\section{BK544}

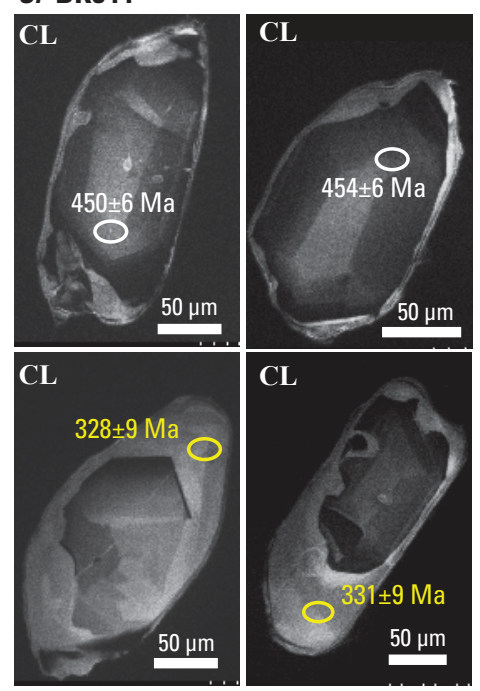

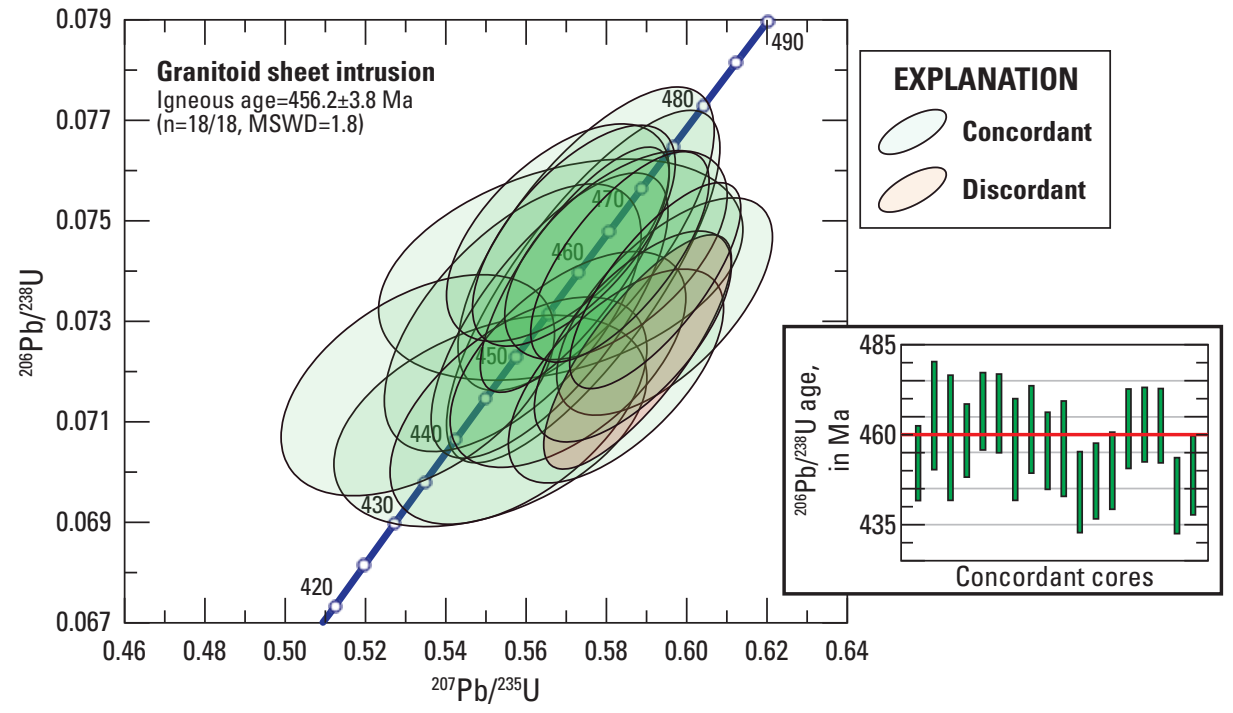
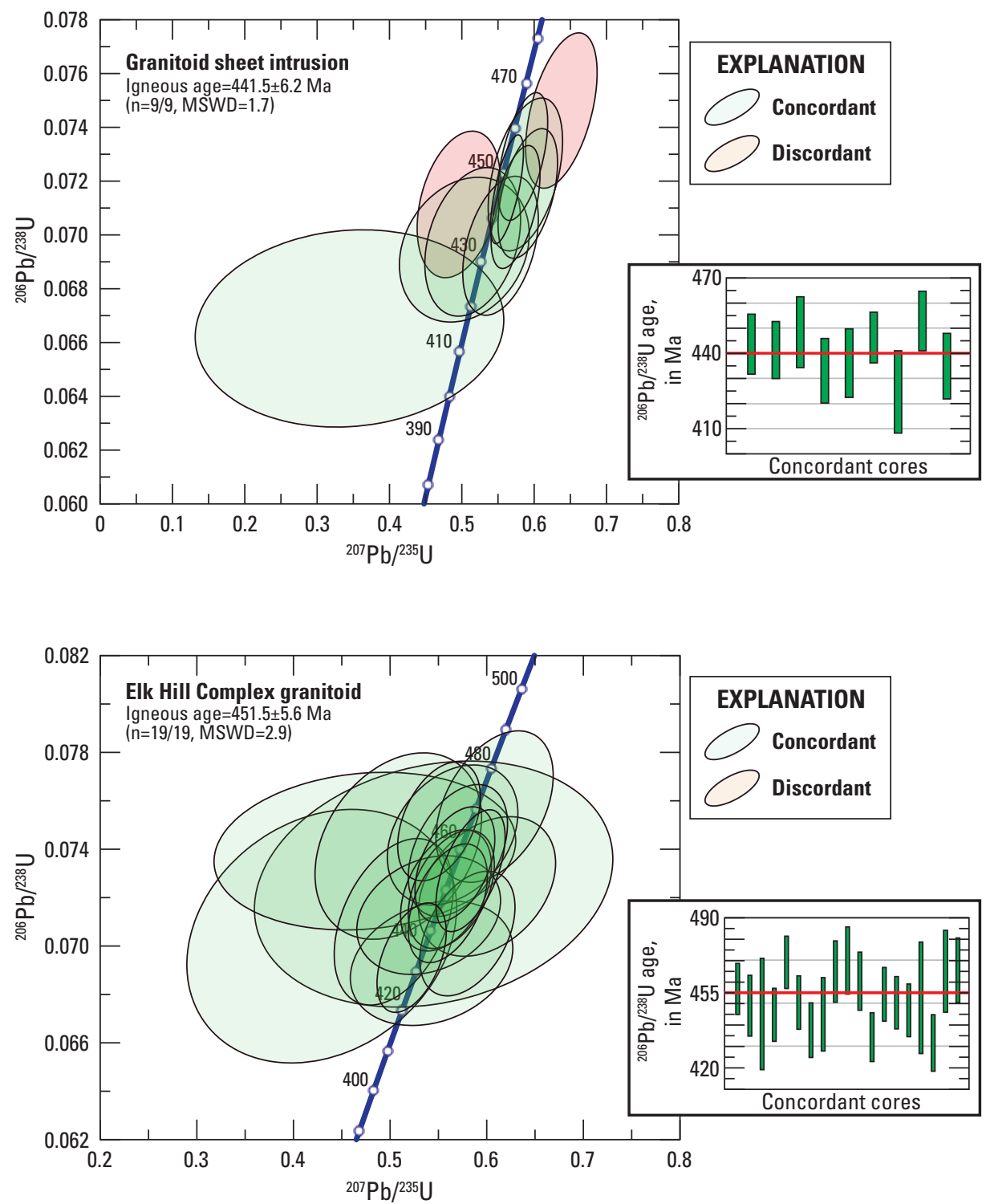
Figure 6. (Left) Scanning electron microscopycathodoluminescence (CL) images of representative zircon grains and plots of isotopic data from the samples analyzed on the Stanford/U.S. Geological Survey sensitive high-resolution ion microprobe-reverse geometry. For all CL image age labels: orange, inherited core; white, igneous crystallization; yellow, metamorphic rim. All concordant (green) and discordant (red) analyses of grain cores are plotted on the concordia diagrams. Only concordant data are plotted on weighted mean diagrams. Data for all analyses can be found in table 3. A, CL images of prismatic zircon showing oscillatory zoned cores, dark mantles, and bright rims in sample BK234 (metagranodioritic sheet intrusion in the eastern belt of the Chopawamsic Formation). Rims embay and truncate zoning in grain cores. Rare inherited grain cores $(\mathrm{n}=3)$ exhibit diffuse $\mathrm{CL}$ zoning with oscillatory outer rims, dark mantles, and bright $\mathrm{CL}$ rims. Concordia and weighted average diagrams are for igneous zircon cores from sample BK234. B, CL images of prismatic zircon showing oscillatory zoned cores, dark mantles, and bright rims in sample BK650 (metagranodioritic sheet intrusion in the eastern belt of the Chopawamsic Formation). Rims embay zoning in grain cores. Concordia and weighted average diagrams are for igneous zircon cores from sample BK650. C, CL images of prismatic zircon showing sector-zoned cores, dark mantles, and bright rims in sample BK544 (metatonalite in the Elk Hill Complex near its north terminus). Rims embay zoning in grain cores. Concordia and weighted average diagrams are for igneous zircon cores from sample BK544. All plots are at 2-sigma. Ma, million years old; MSWD, mean square of weighted deviates; $\mu \mathrm{m}$, micrometer. 

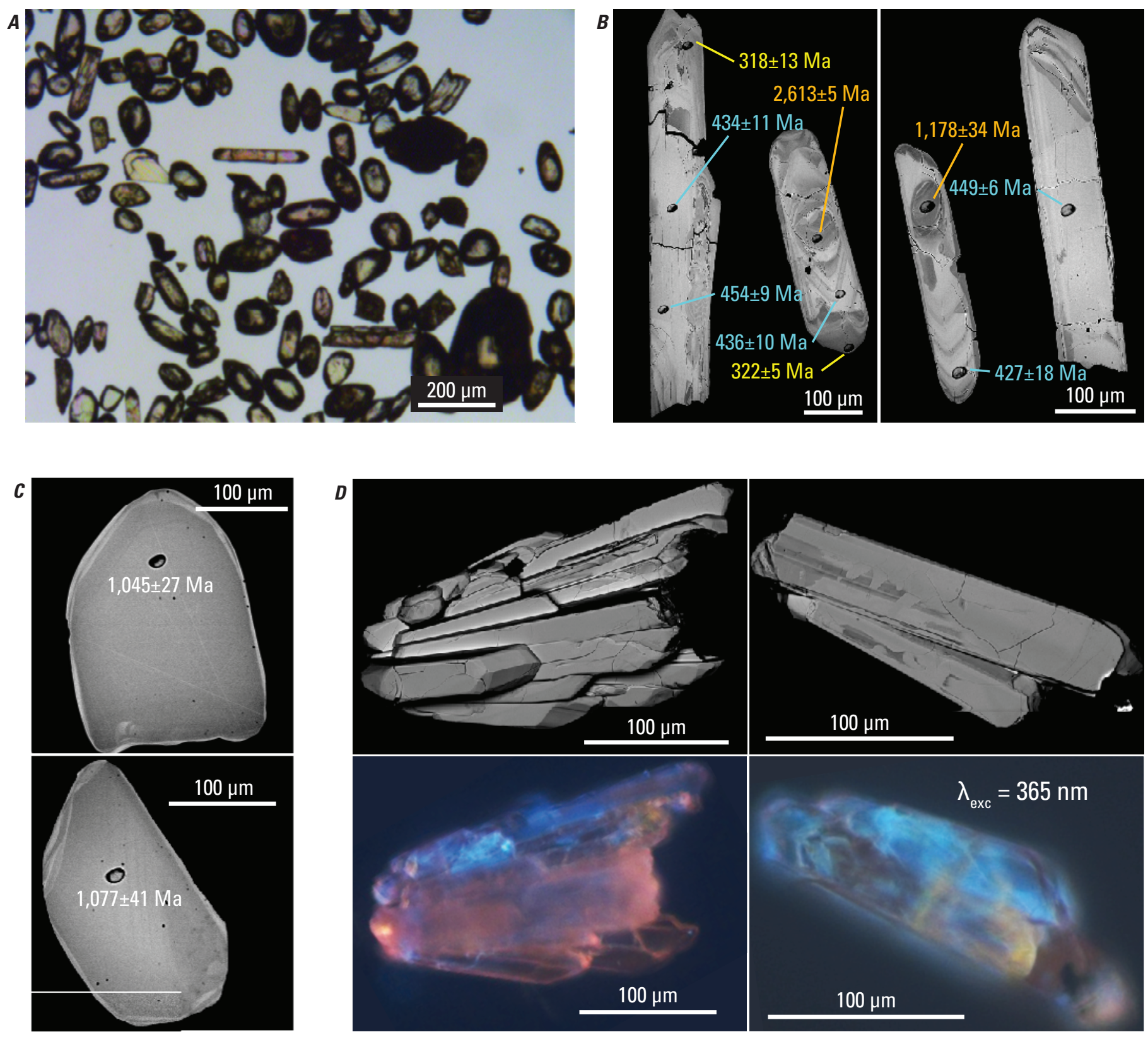

Figure 7. Plane polarized light (PPL), scanning electron microscopy-back-scatter electron (BSE) detector and photoluminescence images of representative zircon grains from sample BK601 (biotite-muscovite migmatitic paragneiss at the northern terminus of the Elk Hill Complex) analyzed on the Stanford/U.S. Geological Survey sensitive high-resolution ion microprobe-reverse geometry. A, PPL image of zircon separate from sample BK601. Stubby ovoid grains are the dominant morphology but elongate dipyramidal grains are also present. $B, \mathrm{BSE}$ images of elongate grains with spot ages indicated $(1 \sigma)$. Two grains have inherited cores and one grain on the left is an aggregate. Age label coloring: orange, inherited core; blue, igneous crystallization age; yellow, metamorphic age. C, BSE images of ovoid grains. The morphology and ages of these grains are consistent with a detrital origin. Data from detrital grains plotted in figure $4 G$ and $H$. $D$, BSE (upper) and photoluminescence (lower) images of rare zircon aggregates. There is significant variance in the photoluminescence response among grains within a single aggregate, suggesting the grains had a different initial crystallization history and then aggregated. Ma, million years old; $\mathrm{nm}$, nanometers; $\mu \mathrm{m}$, micrometers; $\lambda_{\text {exc }}$ excitation wavelength. 

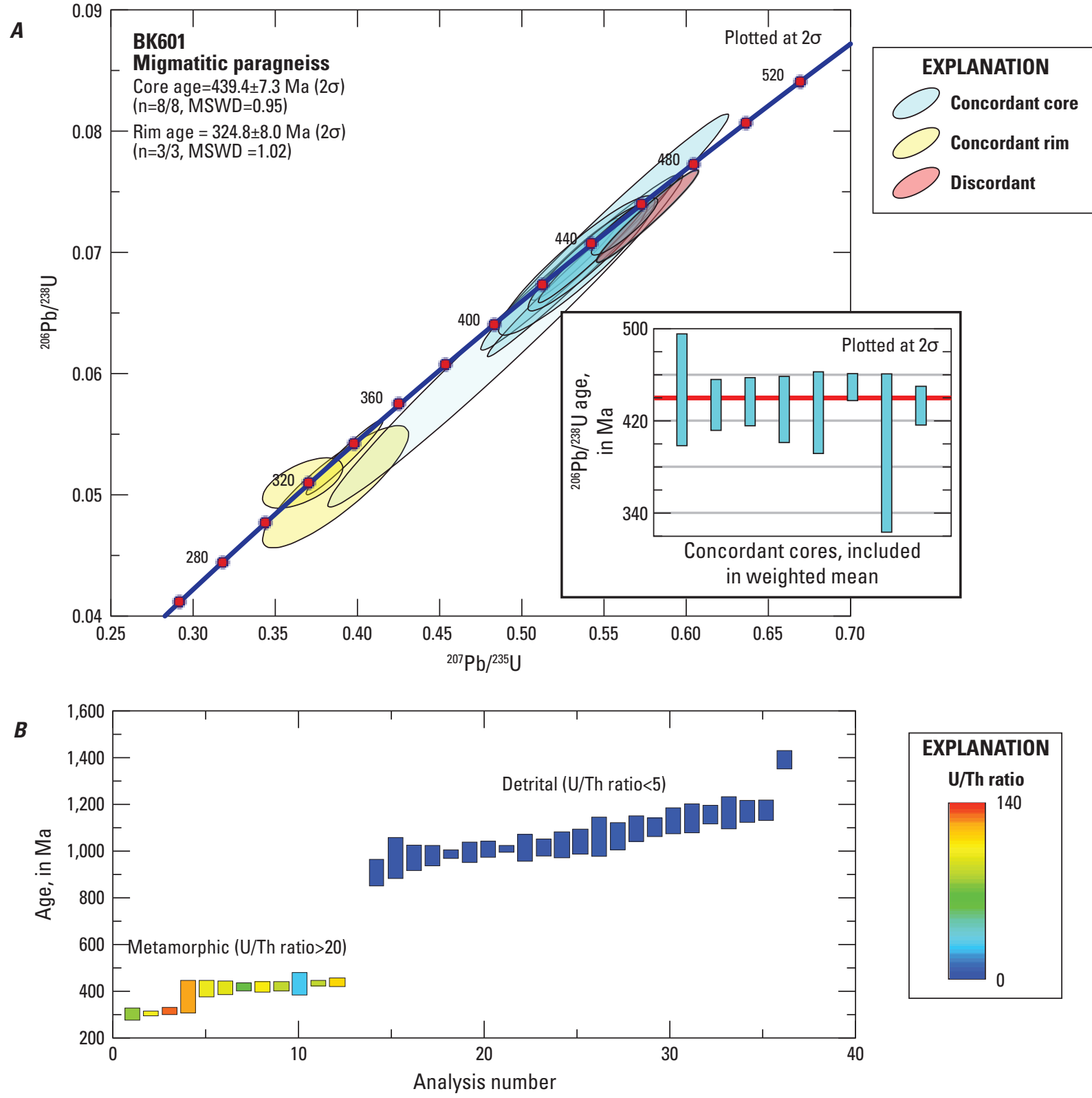

Figure 8. Plots of isotopic data from sample BK601 analyzed on the Stanford/U.S. Geological Survey sensitive high-resolution ion microprobe-reverse geometry. $A$, Concordia plot of analyses from elongate pyramidal grain rims and cores from BK601. Inset: Weighted average plot is for concordant analyses of cores. $B$, Age versus U/Th plot for analyses from sample BK601. Grains with ages older than 900 million years old (Ma) have U/Th ratios $<10$, which is typical of igneous zircon, and grains younger than $500 \mathrm{Ma}$ have $\mathrm{U} / \mathrm{Th}$ ratios $>20$, which is typical of metamorphic zircon (for example, Rubatto, 2017). Data for all analyses can be found in table 2. Ma, million years old; MSWD, mean square of weighted deviates; <, less than; >, greater than. 


\section{Discussion}

Our SHRIMP-RG and LA-ICP-MS zircon geochronology, coupled with new geologic mapping and existing published data, provide new insight into the evolution of the Virginia Piedmont Province. These data assign absolute ages or distinct provenance signatures to previously undated but regionally recognized units, or to new units defined and delineated during recent geologic mapping investigations. This research provides new temporal and geologic constraints concerning the character and duration of Chopawamsic Formation arc volcanism and sedimentation, the onset of post-Taconian successor basin development, and the origin and significance of the Elk Hill Complex on the easternmost margin of the volcanic arc.

\section{Age of the Quantico Formation}

Detrital zircon geochronology supports the interpretation that the Quantico Formation is a successor basin, like the Arvonia Formation (as interpreted by Hughes and others, 2014a). The youngest detrital zircon in the quartzite sample of the Quantico Formation (White Walnut) is $427 \mathrm{Ma}$. The peak age population in the Quantico, at approximately $450 \mathrm{Ma}$ (fig. 4B), suggests a source from local, approximately $450 \mathrm{Ma}$ granitoids and perhaps recycling of the youngest Chopawamsic Formation volcanic arc rocks during deposition of the Quantico Formation. The youngest relative probability peak also compares favorably to detrital zircon ages reported by Hughes and others (2014a) from the stratigraphically highest units in the Arvonia basin - the Bremo Quartzite Member of the Arvonia Formation and overlying Buffards Formation (fig. 9A). These data support the interpretation that the Quantico and Arvonia Formations represent different parts of the same regional successor basin and (or) formed at similar times.

Detailed geologic mapping demonstrates that a sequence of metasedimentary and metavolcanic rocks occurs beneath the typical garnet-mica schist of the Quantico Formation, including thinly interlayered quartzite, felsic gneiss, graphitic schist, and lesser mafic gneiss and greenstone. The quartzite in contact with the overlying garnet-mica schist has been interpreted as the base of the Quantico Formation (for example, Bailey and others, 2005, 2008; Spears and others, 2013) and a detrital zircon as young as approximately $427 \mathrm{Ma}$ from the quartzite (sample White Walnut) supports this interpretation. Map relations show that the unconformity between the Quantico Formation and underlying rocks creates triple-point junctions at map-scale, and there is no evidence for ductile or brittle faulting along the contact. Rocks beneath the contact are also locally aluminum- and iron-enriched (Spears and others, 2013), leading Burton and others (2014) to speculate that they represent metamorphosed soil horizons. The sample of felsic gneiss (sample M16-05-31A) from the base of the Quantico Formation, as defined by these map relations, yielded a
SHRIMP-RG age of $448 \pm 2.2 \mathrm{Ma}$. These data are consistent with the crystallization age of $448 \pm 4 \mathrm{Ma}$ for a felsic lapilli metatuff layer (Horton and others, 2010) mapped in the lower part of the Quantico Formation by Seiders and Mixon (1981) in northern Virginia.

Assigning approximately 448 Ma metavolcanic rocks from our study area to the base of the Quantico Formation is incompatible with the interpretation that these rocks are postorogenic successor basin deposits rather than waning-stage volcanogenic or back-arc basin deposits; in other words, the basin should be no older than the youngest rocks of the previous orogenic cycle over which they are interpreted to have been deposited - in this case, the approximately 444-437 Ma Ellisville pluton. We thus assign these interlayered metasedimentary and metavolcanic rocks to a unit stratigraphically beneath the quartzite of the Quantico Formation but above Chopawamsic Formation rocks (fig. 10).

\section{Age of Long Island Syncline Rocks}

Mesoproterozoic peaks in the sample of the Long Island syncline (ZXR-1) compare well to those in the sample (White Walnut) of quartzite from the Quantico Formation (fig. 9A). The youngest detrital zircon is approximately $467 \mathrm{Ma}$ (fig. $4 C$ and $D$ ), suggesting input from arc rocks of the Chopawamsic Formation, but not from Ordovician-Silurian granitoids (note that the approximately $244 \mathrm{Ma}$ analysis is likely a result of lead-loss or contamination; table 2). The Paleoproterozoic and Neoproterozoic probability peaks in the Long Island syncline sample, however, compare better to pelitic metasedimentary rocks from near Storck, Virginia (fig. 9A), which Hughes and others (2014a) considered to have predominantly a periGondwanan provenance. Comparatively, the Potomac terrane sample (BBF-220; fig. 9B) has a strong Laurentian signature like other Potomac terrane samples from the Piedmont of Virginia (Hughes and others, 2014a; fig. 9B) and southern

Figure 9. (right) Comparative relative probability plots of detrital zircon data from samples dated by laser ablation-inductively coupled plasma-mass spectrometry (samples White Walnut, ZXR-1, and BBF-220 in figure $4 A-F$ ) and sensitive high-resolution ion microprobe-reverse geometry (sample BK601 in figure $4 G$ and $H$ ) during this study, with published data from the central Piedmont in Virginia and Maryland. $A$, Data from the Chopawamsic Formation and overlying successor basin deposits; $B$, Data from the Elk Hill Complex and Potomac terrane units in Virginia and Maryland. Shaded columns designate time periods of terranes and orogenic events that are possible sources of detrital zircon. 


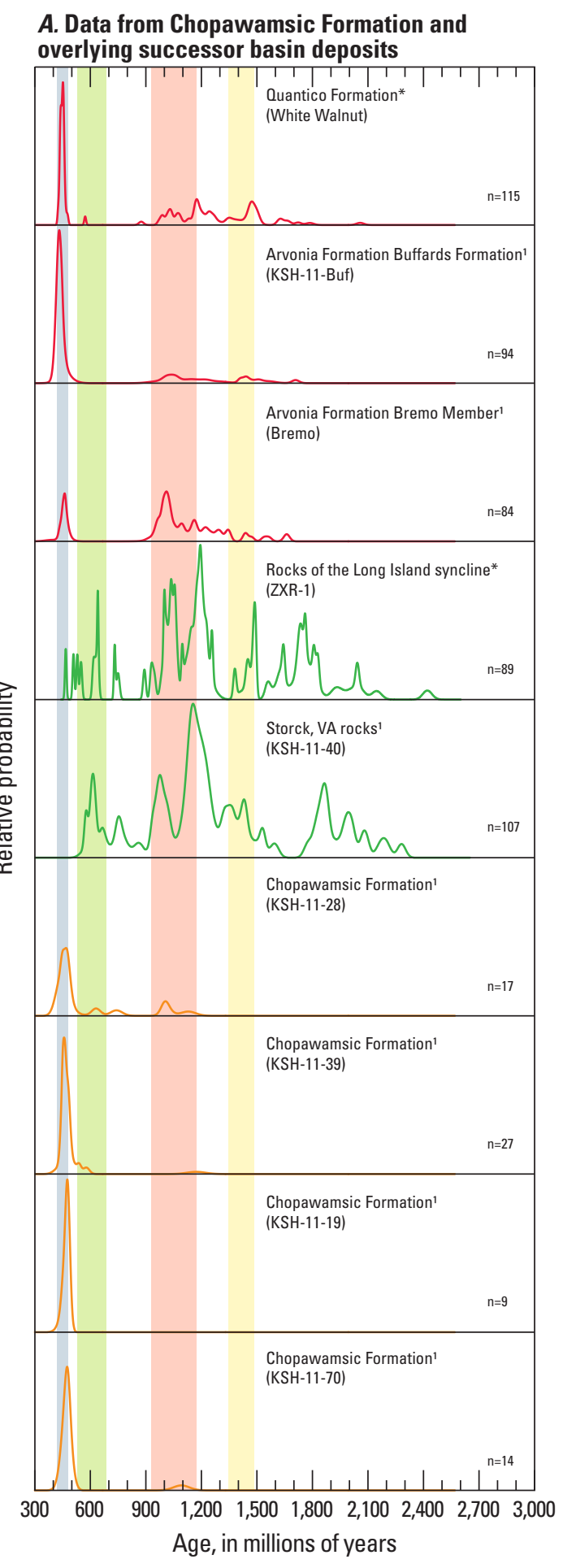

B. Data from the Elk Hill Complex and Potomac terrane units in Virginia and Maryland

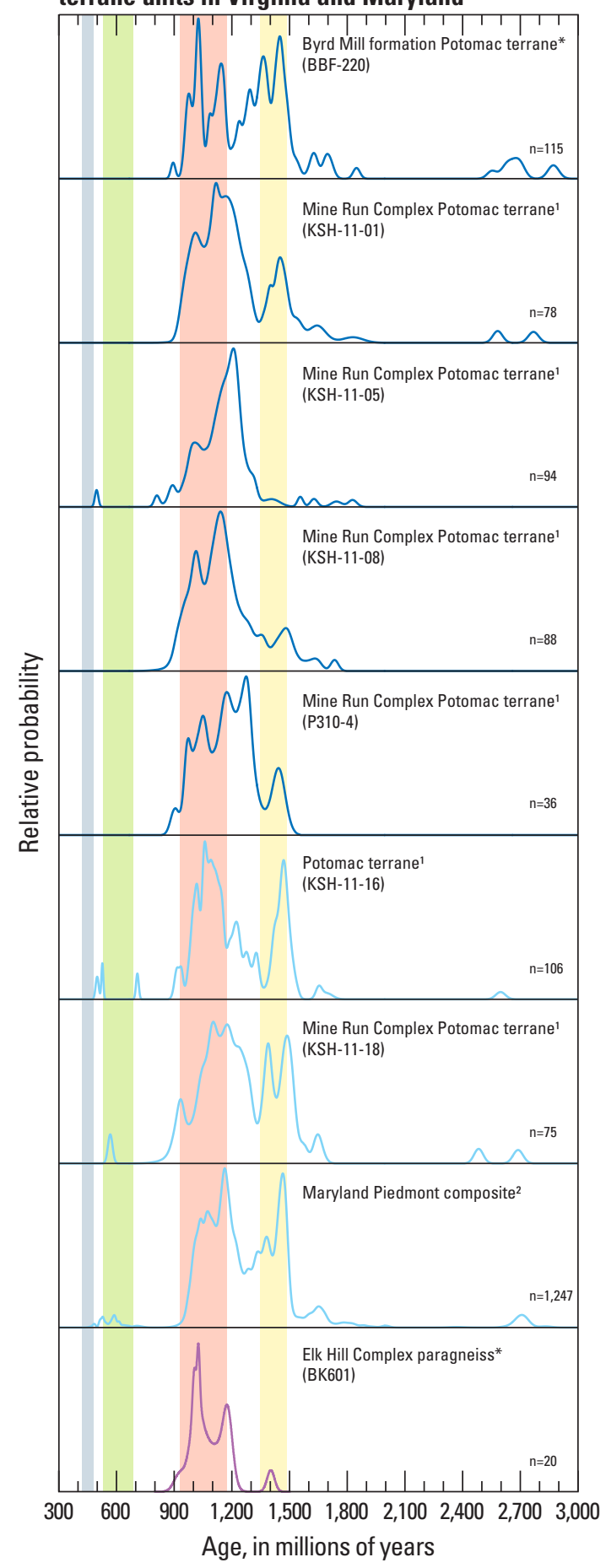

EXPLANATION

Source of rock samples

Time period of terranes and orogenic events

Taconic orogeny

Gondwana-peri-Gondwana

Grenville orogeny

Granite rhyolite province

Data from this study

Published data from Hughes and others (2014a)

Published data from Martin and others (2015)
Quantico and Arvonia Formations

Rocks of the Long Island syncline and rocks at Stork, Virginia

Chopawamsic Formation rocks

Byrd Mill formation and Mine Run Complex rocks of the Potomac terrane Other regional Potomac terrane rocks

Elk Hill Complex paragneiss 


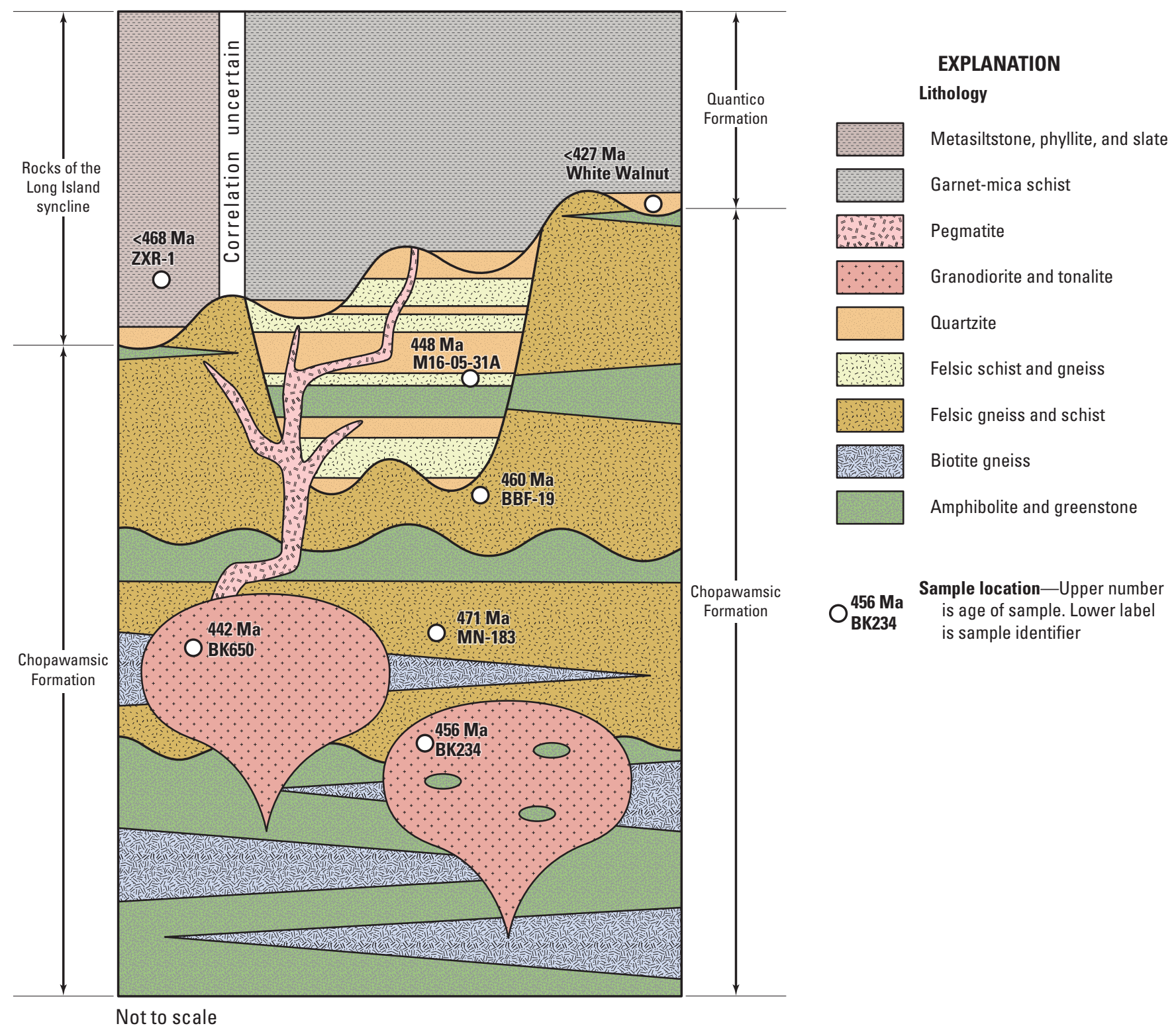

Figure 10. Schematic diagram of Chopawamsic Formation stratigraphy in relation to overlying units and intrusive rocks in the central Virginia Piedmont, based on field relations and geochronology. Ma, million years old. 
Maryland (Martin and others, 2015; fig. 9B). Because the periGondwanan-sourced Long Island syncline and Storck rocks lie in the hanging wall of the Chopawamsic fault, and Laurentian-sourced Potomac terrane rocks compose its footwall, the detrital zircon data confirm that the Chopawamsic fault is a major tectonic boundary. Rocks of the Long Island syncline must have received their peri-Gondwanan zircons from sources currently not exposed at the surface; these peri-Gondwanan source rocks may have either been completely eroded away or were overridden by, and are now buried beneath, the Chopawamsic fault.

\section{Chopawamsic Formation Stratigraphy}

The Chopawamsic Formation is an Ordovician volcanic arc sequence punctuated by internal unconformities and capped by one or more regional unconformities at the top of the unit. Within this framework, the structurally lowest sample (MN-183: quartz phenocryst-bearing felsic schist beneath amphibolite that separates the western belt into lower and upper sections) yielded the oldest age of approximately $471 \mathrm{Ma}$ and the structurally highest sample (BBF-019: metafelsite beneath younger rocks in the core of a syncline subsidiary to the Long Island syncline) yielded an age of $460 \pm 5 \mathrm{Ma}$. These new results are equivalent to previously published ages of 474-465 Ma (for example, Coler and others, 2000; Hughes and others, 2013, 2014a), but extends volcanism in central Virginia by 5 million years and within analytical uncertainty of $453 \pm 4$ Ma volcanism reported by Horton and others (2010) in northern Virginia. These data also provide a lower age bound at $460 \pm 5$ Ma to interlayered metasedimentary and metavolcanics rocks that occur stratigraphically between the Chopawamsic Formation and Quantico Formation (fig. 10). The gap between the schist in the Quantico and this metavolcanic/metasedimentary sequence is supported by additional field relations noted during regional mapping: pegmatites associated with Late Ordovician-early Silurian metagranitoids locally intrude the approximately $448 \mathrm{Ma}$ metavolcanic/ metasedimentary sequence but never the garnet-mica schist of the Quantico Formation.

\section{Age of Granodioritic-tonalitic Sheet Intrusions}

Our SHRIMP-RG U-Pb zircon crystallization ages from two samples of biotite granodiorite range from 456 to $442 \mathrm{Ma}$. These data indicate that granodioritic intrusions east of the Quantico synclinorium are coeval with granodiorite of the Ellisville pluton (Pavlides and others, 1994) west of the synclinorium. The occurrence of magmatic epidote in both the Ellisville pluton granodiorite (Pavlides and others, 1994; Hughes and others, 2013) and metagranodiorite-metatonalite east of the Quantico synclinorium (fig. 4C) indicates similar depths of emplacement in the lower crust, under moderately high pressure and oxidizing conditions (Zen and Hammarstrom, 1984).

\section{Metamorphic and Structural Considerations Along the East Flank of the Chopawamsic Terrane}

Our SHRIMP-RG U-Pb zircon data provide evidence for Ordovician deformation east of the Quantico synclinorium. Within the Elk Hill Complex, foliation in amphibolite xenoliths is truncated by surrounding approximately $452 \mathrm{Ma}$ granodioritic and tonalitic gneiss (fig. $4 E$ ), and therefore must have formed prior to $452 \mathrm{Ma}$. Further evidence for Ordovician metamorphism is provided by SHRIMP-RG ages of approximately $440 \mathrm{Ma}$ for elongate zircon in biotite-muscovite migmatitic paragneiss (fig. $7 B$ ). These zircon grains have high $\mathrm{U} / \mathrm{Th}$ ratios typical of zircon that is metamorphic in origin (fig. 8B). The elongate, dipyramidal morphology, however, is more typical of igneous zircon, and solid-state growth of these elongate zircon grains is difficult to envision. Furthermore, UV imaging of zircon aggregates demonstrates that aggregates are composed of individual grains with varying UV response (fig. 7D). In that the UV response is chiefly a function of radiation damage (in other words, U+Th concentration; Gaft, 1992), this indicates high compositional variance and suggests that the individual grains did not form from the same melt, but rather had a different initial crystallization history and then aggregated - that is, they formed by synneusis (Jocelyn and Pidgeon, 1974). This process of postgrowth aggregation is inconsistent solid-state growth and strongly suggests the presence of melt (Prasad, 1975). We therefore suggest that the elongate grains grew in the migmatitic melt and record migmatization at approximately $440 \mathrm{Ma}$. The age also overlaps with the crystallization age of the youngest regional sheet intrusions. Rim ages of approximately $325 \mathrm{Ma}$ (fig. 7B) on this sample (BK601) and sample BK544 from the Elk Hill Complex (fig. $6 \mathrm{C}$ ) are consistent with regional Alleghanian metamorphism.

At the northernmost terminus of the Elk Hill Complex (fig. 2), the Alleghanian Lakeside fault is marked by a thin belt of S-C mylonitic phyllonite that tips out into a tight antiform of biotite-muscovite migmatitic paragneiss. Detailed geologic mapping demonstrates that biotite-muscovite paragneiss is structurally concordant above the easternmost Chopawamsic Formation (in other words, foliation is parallel to the contact in both paragneiss and Chopawamsic Formation rocks) on the flanks of the antiform. The paragneiss yields Paleoproterozoic to Neoproterozoic (Laurentian) peak age populations (figs. $3 D$ and $7 C$ ) that are mostly absent in Chopawamsic Formation rocks (fig. $9 \mathrm{~A}$ ), which suggests that the contact might be a premetamorphic (pre-Alleghanian) fault or an overturned unconformity. Juxtaposition of migmatitic paragneiss with penetratively deformed but nonmigmatitic interlayered felsic and mafic gneiss of the Chopawamsic Formation is the only field evidence for faulting along this contact. Ordovician displacement along this potential fault contact may have been significant to juxtapose rocks from differing crustal levels. These data also suggest that Alleghanian ductile folding during 
amphibolite-facies metamorphism within the Chopawamsic terrane was a more important contributor to Alleghanian shortening in this part of the central Virginia Piedmont than Alleghanian ductile fault displacement, and that the more significant Alleghanian fault east of the Taconic Chopawamsic fault is the Spotsylvania high-strain zone, which marks the contact between the Elk Hill Complex and the Goochland terrane to the east.

\section{Conclusions}

Our SHRIMP-RG and LA-ICP-MS U-Pb zircon geochronologic data allow us to draw the following five conclusions about the tectonostratigraphic composition of the central Virginia Piedmont:

1. The basal quartzite of the Quantico Formation has a maximum depositional age of approximately $427 \mathrm{Ma}$, indicating that the formation is a successor basin to the volcanic arc represented by the Chopawamsic Formation. The basal quartzite is composed of mostly detritus from the Chopawamsic terrane and the numerous intrusions within it.

2. Rocks of the Long Island syncline have a strong periGondwanan detrital zircon provenance signature, like the rocks near Storck, in the northern Virginia Piedmont. These rocks are likely not part of the Chopawamsic Formation but are part of a separate basin that developed above or near the arc.

3. Volcanism and arc development represented by the Chopawamsic Formation lasted from roughly 474 to at least $460 \mathrm{Ma}$. Felsic gneiss within a sequence of interlayered metasedimentary and metavolcanic rocks bounded by unconformities above the typical approximately $460 \mathrm{Ma}$ Chopawamsic arc rocks and beneath approximately $427 \mathrm{Ma}$ Quantico Formation yields an age of approximately $448 \mathrm{Ma}$. This unit consists of thinly interlayered and interbedded felsic volcanic rocks, quartzite, and graphitic schist, and likely represents the youngest part of the Chopawamsic arc.

4. Hornblende-biotite granodioritic and tonalitic sheet intrusions in the eastern belt of the Chopawamsic Formation are approximately 150 million years older than previously thought. The term "Elk Creek pluton" of Mixon and others (2000) may be retained, but its Ordovician to Silurian age means that the rocks can no longer be correlated with the Carboniferous Falmouth Intrusive Suite.

5. Biotite-muscovite migmatitic paragneiss preserves evidence for Ordovician high-grade metamorphism on the east flank of the Chopawamsic terrane. The age of this unit, based on limited detrital zircon geochronologic data, suggests that the structurally concordant contact between the paragneiss and layered mafic and felsic rocks of the Chopawamsic Formation is either a premetamorphic (pre-Alleghanian) fault or an overturned unconformable contact, which would place paragneiss as Laurentian-sourced basement beneath arc volcanic rocks of the Chopawamsic Formation. The Lakeside fault, which separates the Elk Hill Complex from the Chopawamsic Formation along its length, tips out into an antiform of biotite-muscovite migmatitic paragneiss at the northernmost terminus of the Elk Hill Complex. 


\section{References Cited}

Bailey, C., Eriksson, K., Allen, C., and Campbell, I., 2008, Detrital zircon geochronology of the Chopawamsic terrane, Virginia Piedmont-Evidence for a non-Laurentian provenance [abs.]: Geological Society of America Abstracts with Programs, v. 40, no. 6, p. 449.

Bailey, C., Koteas, C., Relyea, J., Weikel, E., Dubose, J., and Goodman, M., 2005, Geologic map of the Columbia 7.5' quadrangle, Virginia: Virginia Department of Mines, Minerals, and Energy Open File Report 05-02, scale 1:24,000.

Bailey, C.M., Francis, B.E., and Fahrney, E.E., 2004, Strain and vorticity analysis of transpressional high-strain zones from the Virginia Piedmont, USA, in Alsop, G.I., Holdsworth, R.E., McCaffrey, K.J.W., and Hand, M., eds., Flow processes in faults and shear zones: Geological Society of London Special Publication 224, p. 249-264. [Also available at https://doi.org/10.1144/GSL.SP.2004.224.01.16.

Barth, A.P., and Wooden, J.L., 2010, Coupled elemental and isotopic analyses of polygenetic zircons from granitic rocks by ion microprobe, with implications for melt evolution and the sources of granitic magmas: Chemical Geology, v. 277, no. 1-2, p. 149-159, accessed September 2019 at https://doi. org/10.1016/j.chemgeo.2010.07.017.

Black, L.P., Kamo, S.L., Allen, C.M., Davis, D.W., Aleinikoff, J.N., Valley, J.W., Mudil, R., Campbell, I.H., Korsch, R.J., Williams, I.S., and Foudoulis, C., 2004, Improved ${ }^{206} \mathrm{~Pb} /{ }^{238} \mathrm{U}$ microprobe geochronology by the monitoring of a trace-element-related matrix effect; SHRIMP, ID-TIMS, ELA-ICPMS and oxygen isotope documentation for a series of zircon standards: Chemical Geology, v. 205, no. 1-2, p. 115-140, accessed September 2019 at https://doi.org/10.1016/j.chemgeo.2004.01.003.

Bobyarchick, A.R., Pavlides, L., and Wier, K., 1981, Piedmont geology of the Ladysmith and Lake Anna East quadrangles, and vicinity, Virginia: U.S. Geological Survey Miscellaneous Investigations Series Map I-1282, scale 1:24,000.

Bourland, W.C., Glover, L., III, and Poland, F.B., 1979, Lakeside Fault Zone, in Glover, L., III, ed., Guides to field trips 1-3, Southeastern Section meeting, Geological Society of America: Blacksburg, Virginia Polytechnic Institute and State University, p. 17-18.

Brown, W.R., 1969, Geology of the Dillwyn quadrangle, Virginia: Virginia Division of Mineral Resources Report of Investigations 10, $77 \mathrm{p}$.

Brown, W.R., 1986, Shores Complex and mélange in the central Virginia Piedmont, in Neathery, T.L., ed., Southeastern Section of the Geological Society of America, centennial field guide: Geological Society of America, The Decade of North American Geology (DNAG), v. 6, p. 209-214.
Burton, W.C., Harrison, R.W., Spears, D.B., Evans, N.H., and Mahan, S., 2015a, Geologic framework and evidence for neotectonism in the epicentral area of the 2011 Mineral, Virginia, earthquake, in Horton, J.W., Jr., Chapman, M.C., and Green, R.A., eds., The 2011 Mineral, Virginia, earthquake, and its significance for seismic hazards in eastern North America: Geological Society of America Special Paper 509, p. 391-406, accessed September 2019 at https:// doi.org/10.1130/2015.2509(20).

Burton, W.C., Kunk, M.J., Spears, D.B., Evans, N.H., and McAleer, R.J., 2015b, Taconian orogenesis and Alleghanian overprinting in central Virginia Piedmont as revealed by new ${ }^{40} \mathrm{Ar} /{ }^{39} \mathrm{Ar}$ data [abs.]: Geological Society of America Abstracts with Programs, v. 47, no. 2, p. 21.

Burton, W.C., Spears, D.B., Harrison, R.W., Evans, N.H., Schindler, J.S., and Counts, R., 2014, Geology and neotectonism in the epicentral area of the 2011 M5.8 Mineral, Virginia, earthquake, in Bailey, C.M., and Coiner, L.V., eds., Elevating geoscience in the southeastern United States-New ideas about old terranes: Geological Society of America Southeastern Section meeting, Blacksburg, Va., Field Guide 35, p. 103-127, accessed September 2019 at https://doi.org/10.1130/2014.0035(04).

Coler, D.G., Wortman, G.L., Samson, S.D., Hibbard, J.P., and Stern, R., 2000, U-Pb geochronologic, Nd isotopic, and geochemical evidence for the correlation of the Chopawamsic and Milton terranes, Piedmont Zone, southern Appalachian orogen: The Journal of Geology, v. 108, no. 4, p. 363-380, accessed September 2019 at https://doi.org/10.1086/314411.

Evans, N.H., 1984, Lithofacies of the Virginia Blue Ridge and Hardware terranes-Evidence for pre-Middle Ordovician volcanic arc accretion, in latest Precambrian to Ordovician metamorphism and orogenesis in the Blue Ridge and western Piedmont, Virginia Appalachians: Blacksburg, Virginia Polytechnic Institute and State University, Ph.D. dissertation, $313 \mathrm{p}$.

Evans, N.H., 2017, Geologic map of the Zion Crossroads quadrangle, Virginia: Virginia Division of Geology and Mineral Resources, 2017 VDGMR STATEMAP, scale 1:24,000.

Evans, N.H., and Farrar, S., 2015, Geologic map of the Perkinsville quadrangle, Virginia: Virginia Division of Geology and Mineral Resources, 2015 VDGMR STATEMAP, scale 1:24,000.

Gaft, M., 1992, Application of thermal treatment of zircon for the interpretation of luminescence centers: Journal of Thermal Analysis and Calorimetry, v. 38, no. 10, p. 2281-2290, accessed September 2019 at https://doi.org/10.1007/ BF02123981. 
Gehrels, G., 2012, Detrital zircon U-Pb geochronology-Current methods and new opportunities, in Busby, C., and Azor, A., eds., Tectonics of sedimentary basins - Recent Advances: Hoboken, N.J., Wiley-Blackwell Publishing p. 47-62, accessed September 2019 at https://doi. org/10.1002/9781444347166.ch2.

Glover, L., III, 1989, Tectonics of the Virginia Blue Ridge and Piedmont, Culpeper to Richmond, Virginia: American Geophysical Union Field Trip Guidebook T363, 28th International Geological Congress, Washington, D.C., 59 p.

Goodwin, B.K., 1970, Geology of the Hylas and Midlothian quadrangles, Virginia: Virginia Division of Mineral Resources Report of Investigations 23, 67 p.

Hibbard, J.P., van Staal, C.R., Rankin, D.W., and Williams, H., 2006, Lithotectonic map of the Appalachian orogen, Canada-United States of America: Geological Survey of Canada Map 2096A, scale 1:1,500,000, 2 sheets.

Hopkins, H.R., 1960, Geology of western Louisa County, Virginia: Ithaca, Cornell University, Ph.D. dissertation, 98 p.

Horton, J.W., Jr., Aleinikoff, J.N., Drake, A.A., Jr., and Fanning, C.M., 2010, Ordovician volcanic-arc terrane in the central Appalachian Piedmont of Maryland and VirginiaSHRIMP U-Pb geochronology, field relations, and tectonic significance, in Tollo, R.P., Bartholomew, M.J., Hibbard, J.P., and Karabinos, P.M., eds., From Rodinia to PangeaThe lithotectonic record of the Appalachian region: Geological Society of America Memoir 206, p. 621-660, accessed September 2019 at https://doi.org/10.1130/2010.1206(25).

Horton, J.W., Jr., Drake, A.A., Jr., and Rankin, D.W., 1989, Tectonostratigraphic terranes and their Paleozoic boundaries in the central and southern Appalachians, in Dallmeyer, R.D., ed., Terranes in the circum-Atlantic Paleozoic orogens: Geological Society of America Special Paper 230, p. 213-245, accessed September 2019 at https://doi. org/10.1130/SPE230-p213.

Horton, J.W., Jr., and Williams, R., 2012, The 2011 Virginia earthquake-What are scientists learning?: Eos, v. 93, no. 33, p. 317-318, accessed September 2019 at https://doi. org/10.1029/2012EO330001.

Hu, Z., Gao, S., Liu, Y., Hu, S., Chen, H., and Yuan, H., 2008, Signal enhancement in laser ablation ICP-MS by addition of nitrogen in the central channel gas: Journal of Analytical Atomic Spectrometry, v. 23, no. 8, p. 1093-1101, accessed September 2019 at https://doi.org/10.1039/b804760j.

Hughes, K.S., 2014, Does the Chopawamsic fault represent the main Iapetan suture in the Southern Appalachian orogen? Geology, geochemistry, and geochronology of the western Piedmont of Virginia and insight into local intraplate seismicity: Raleigh, North Carolina State University, Ph.D. dissertation, 320 p., 1:24,000-scale plate.
Hughes, K.S., Hibbard, J.P., and Bohnenstiehl, D.R., 2015, Relict Paleozoic faults in the epicentral area of the 23 August 2011 central Virginia earthquake-Assessing the relationship between preexisting strain and modern seismicity, in Horton, J.W., Jr., Chapman, M.C., and Green, R.A., eds., The 2011 Mineral, Virginia, earthquake, and its significance for seismic hazards in eastern North America: Geological Society of America Special Paper 509, p. 331-343, accessed September 2019 at https://doi. org/10.1130/2014.2509(19).

Hughes, K.S., Hibbard, J.P., and Miller, B.V., 2013, Relationship between the Ellisville pluton and Chopawamsic fault_-Establishment of significant Late Ordovician faulting in the Appalachian Piedmont of Virginia: American Journal of Science, v. 313, no. 6, p. 584-612, accessed September 2019 at https://doi.org/10.2475/06.2013.03.

Hughes, K.S., Hibbard, J.P., Pollock, J.C., Lewis, D.J., and Miller, B.V., 2014a, Detrital zircon geochronology across the Chopawamsic fault, western Piedmont of North-Central Virginia-Implications for the main Iapetan suture in the southern Appalachian orogen: Geoscience Canada, v. 41, no. 4, p. 1-20, accessed September 2019 at https://doi. org/10.12789/geocanj.2014.41.052.

Hughes, K.S., Hibbard, J.P., Sauer, R.T., and Burton, W.C., 2014b, Stitching the western Piedmont of Virginia-Tectonic significance of the Ellisville pluton and the Potomac and Chopawamsic terranes in the early Paleozoic: Virginia Geological Field Conference, October 10-11, 2014, Virginia Museum of Natural History Publications Guidebook Number 9, $33 \mathrm{p}$.

Jocelyn, J., and Pidgeon, R.T., 1974, Examples of twinning and parallel growth in zircons from some Precambrian granites and gneisses: Mineralogical Magazine, v. 39, no. 305, p. 587-594, accessed September 2019 at https:// doi.org/10.1180/minmag.1974.039.305.13.

Kolata, D.R., and Pavlides, L., 1986, Echinoderms from the Arvonia Slate, central Virginia Piedmont: Geologica et Palaeontologica, v. 20, p. 1-9.

Ludwig, K.R., 2009, SQUID 2, A user's manual (rev 2.50): Berkeley Geochronology Center Special Publication 5, 110 p., accessed September 2019 at http://bgc.org/isoplot_ etc/squid/SQUID2_5Manual.pdf.

Ludwig, K.R., 2012, User's manual for Isoplot 3.75-A geochronological toolkit for Microsoft Excel: Berkeley Geochronology Center Special Publication 5, 75 p., accessed September 2019 at http://www.bgc.org/isoplot_etc/isoplot/ Isoplot3_75-4_15manual.pdf.

Luttrell, G.W., 1966, Base- and precious-metals and related ore deposits of Virginia: Virginia Division of Mineral Resources Mineral Resources Report 7, 174 p. 
Marr, J.D., Jr., 2002, Geologic map of the western portion of the Richmond 30 x 60 minute quadrangle, Virginia: Virginia Division of Mineral Resources Publication 165, scale 1:100,000.

Martin, A.J., Southworth, C.S., Collins, J.C., Fisher, S.W., and Kingman, E.R., III, 2015, Laurentian and Amazonian sediment sources to Neoproterozoic-lower Paleozoic Maryland Piedmont rocks: Geosphere, v. 11, no. 4, p. 1042-1061, accessed September 2019 at https://doi.org/10.1130/ GES01140.1.

McAleer, R.J., Burton, W.C., Carter, M.W., Kunk, M.J., and Spears, D.B., 2017, Tectonothermal signatures of Taconian and Alleghanian orogenesis in the Central Virginia Seismic Zone [abs.]: Geological Society of America Abstracts with Programs, v. 49, no. 3, accessed September 2019 at https:// doi.org/10.1130/abs/2017SE-290009.

Mixon, R.B., Pavlides, L., Powars, D.S., Froelich, A.J., Weems, R.E., Schindler, J.S., Newell, W.L., Edwards, L.E., and Ward, L.W., 2000, Geologic map of the Fredericksburg 30' X 60' quadrangle, Virginia and Maryland: U.S. Geological Survey Geologic Investigations Series Map I-2607, scale 1:100,000, 2 plates, 34 p. pamphlet.

Paces, J.B., and Miller, J.D., Jr., 1993, Precise U-Pb ages of Duluth Complex and related mafic intrusions, northeastern Minnesota - Geochronological insights to physical, petrogenetic, paleomagnetic and tectono-magmatic processes associated with the $1.1 \mathrm{Ga}$ midcontinent rift system: Journal of Geophysical Research, v. 98, no. B8, p. 13997-14013, accessed September 2019 at https://doi. org/10.1029/93JB01159.

Paton, C., Hellstrom, J., Paul, B., Woodhead, J., and Hergt, J., 2011, Iolite-Freeware for the visualization and processing of mass spectrometric data: Journal of Analytical Atomic Spectrometry, v. 26, no. 12, p. 2508-2518, accessed September 2019 at https://doi.org/10.1039/c1ja10172b.

Pavlides, L., 1980, Revised nomenclature and stratigraphic relationships of the Fredericksburg Complex and Quantico Formation of the Virginia Piedmont: U.S. Geological Survey Professional Paper 1146, 29 p.

Pavlides, L., 1981, The central Virginia volcanic-plutonic belt - An island arc of Cambrian(?) age: U.S. Geological Survey Professional Paper 1231-A, 34 p., accessed September 2019 at https://doi.org/10.3133/pp1231A.

Pavlides, L., 1989, Early composite mélange terrane, central Appalachian Piedmont, Virginia and Maryland; Its origin and tectonic history, in Horton, W., and Rast, N., eds., Mélanges and olistostromes of the U.S. Appalachians: Geological Society of America Special Paper 228, p. 135-194.
Pavlides, L., 1990, Geology of part of the northern Virginia Piedmont: U.S. Geological Survey Open-File Report 90-548, scale 1:100,000.

Pavlides, L., 1994, Continental margin deposits and the Mountain Run fault zone of Virginia; Stratigraphy and tectonics, in Drake, A.A., Jr., and Pavlides, L., eds., Stratigraphic notes, 1993: U.S. Geological Survey Bulletin 2076-B, 9 p.

Pavlides, L., 1995, Piedmont geology of the Stafford, Storck, Salem Church, and Fredericksburg quadrangles, Stafford, Fauquier, and Spotsylvania Counties, Virginia: U.S. Geological Survey Open-File Report 95-577, scale 1:24,000.

Pavlides, L., Arth, J.G., Sutter, J.F., Stern, T.W., and Cortesini, H., Jr., 1994, Early Paleozoic alkalic and calc-alkalic plutonism and associated contact metamorphism, central Virginia Piedmont: U.S. Geological Survey Professional Paper 1529, 147 p., map scales 1:250,000 (pl. 1) and 1:100,000 (pl. 2).

Pavlides, L., Gair, J.E., and Cranford, S.L., 1982a, Central Virginia volcanic-plutonic belt as a host for massive sulfide deposits: Economic Geology and the Bulletin of the Society of Economic Geologists, v. 77, no. 2, p. 233-272, accessed September 2019 at https://doi.org/10.2113/gsecongeo.77.2.233.

Pavlides, L., Pojeta, J., Jr., Gordon, M., Jr., Parsley, R.L., and Bobyarchick, A.R., 1980, New evidence for the age of the Quantico Formation of Virginia: Geology, v. 8, no. 6, p. 286-290, accessed September 2019 at https://doi. org/10.1130/0091-7613(1980)8<286:NEFTAO>2.0.CO;2.

Pavlides, L., Stern, T.W., Arth, J.G., Muth, K.G., and Newell, M.F., 1982b, Middle and upper Paleozoic rocks in the Piedmont near Fredericksburg, Virginia-Geochronology: U.S. Geological Survey Professional Paper 1231-B, 9 p., accessed September 2019 at https://doi.org/10.3133/ pp1231B.

Prasad, E.A.V., 1975, Monomineralic synneusis in zircon: Current Science, v. 44, p. 759-761.

Roig, C.I., Hughes, K.S., and Miller, B.V., 2017, Age and tectonic significance of the Elk Hill Complex and Pegmatite Belt, central Appalachian Piedmont, Virginia, USA [abs.]: Geological Society of America Abstracts with Programs, v. 49, no. 3, accessed September 2019 at https://doi. org/10.1130/abs/2017SE-290137.

Rossman, D.L., 1991, Geology and mineral resources of the Boswell Tavern and Keswick quadrangles, Virginia: Virginia Division of Mineral Resources Publication 107, 34 p.

Rubatto, D., 2017, Zircon-The metamorphic mineral: Reviews in Mineralogy and Geochemistry, v. 83, no. 1, p. 261-295, accessed September 2019 at https://doi. org/10.2138/rmg.2017.83.9. 
Sauer, R.T., 1984, A metamorphosed stratiform alteration zone as footwall to massive sulfide, Mineral District, Virginia: London, Ontario, Canada, University of Western Ontario (Western University), M.S. thesis, 196 p.

Seiders, V.M., and Mixon, R.B., 1981, Geologic map of the Occoquan quadrangle and part of the Fort Belvoir quadrangle, Prince William and Fairfax counties, Virginia: U.S. Geological Survey Miscellaneous Investigations Map I-1175, scale 1:24,000, 1 sheet.

Sinha, A.K., Thomas, W.A., Hatcher, R.D., Jr., and Harrison, T.M., 2012, Geodynamic evolution of the central Appalachian orogen - Geochronology and compositional diversity of magmatism from Ordovician through Devonian: American Journal of Science, v. 312, no. 8, p. 907-966, accessed September 2019 at https://doi.org/10.2475/08.2012.03.

Sláma, J., Košler, J., Condon, D.J., Crowley, J.L., Gerdes, A., Hanchar, J.M., Horstwood, M.S.A., Morris, G.A., Nasdala, L., Norberg, N., Schaltegger, U., Schoene, B., Tubrett, M.N., and Whitehouse, M.J., 2008, Plešovice zircon-A new natural reference material for $\mathrm{U}-\mathrm{Pb}$ and $\mathrm{Hf}$ isotopic microanalysis: Chemical Geology, v. 249, no. 1-2, p. 1-35, accessed September 2019 at https://doi.org/10.1016/j.chemgeo.2007.11.005.

Smith, J.W., Milici, R.C., and Greenberg, S.S., 1964, Geology and mineral resources of Fluvanna County: Virginia Division of Mineral Resources Bulletin 79, 62 p.

Southwick, D.L., Reed, J.C., Jr., and Mixon, R.B., 1971, The Chopawamsic Formation-A new stratigraphic unit in the Piedmont of northern Virginia: U.S. Geological Survey Bulletin 1324-D, $11 \mathrm{p}$.

Spears, D.B., 2011, Geology of the Lakeside Village quadrangle, Virginia: Virginia Division of Geology and Mineral Resources Publication 177, scale 1:24,000.

Spears, D.B., Evans, N.H., and Gilmer, A.K., 2013, Geologic map of the Pendleton quadrangle, Virginia: Virginia Division of Geology and Mineral Resources, 2013 VDGMR STATEMAP, scale 1:24,000.

Spears, D.B., Owens, B.E., and Bailey, C.M., 2004, The Goochland-Chopawamsic terrane boundary, central Virginia Piedmont, in Southworth, S., and Burton, W.C., eds., Geology of the National Capital Region-Field trip guidebook: U.S. Geological Survey Circular 1264, p. 223-245.
Spencer, C.J., Kirkland, C.L., and Taylor, R.J., 2016, Strategies towards statistically robust interpretations of in situ $\mathrm{U}-\mathrm{Pb}$ zircon geochronology: Geoscience Frontiers, v. 7, no. 4, p. 581-589, accessed September 2019 at https://doi. org/10.1016/j.gsf.2015.11.006.

Stacey, J.S., and Kramers, J.D., 1975, Approximation of terrestrial lead isotope evolution by a two-stage model: Earth and Planetary Science Letters, v. 26, no. 2, p. 207-221, accessed September 2019 at https://doi.org/10.1016/0012821X(75)90088-6.

Steiger, R.H., and Jäger, E., 1977, Subcommission on geochronology - Convention on the use of decay constants in geo- and cosmochronology: Earth and Planetary Science Letters, v. 36, no. 3, p. 359-362, accessed September 2019 at https://doi.org/10.1016/0012-821X(77)90060-7.

Taber, S., 1913, Geology of the gold belt in the James River Basin, Virginia: Virginia Geological Survey Bulletin 7, $271 \mathrm{p}$.

Virginia Division of Mineral Resources, 1993, Geologic map of Virginia: Virginia Department of Mines, Minerals and Energy, Division of Geology and Mineral Resources, scale 1:500,000.

Watson, T.L., and Powell, S.L., 1911, Fossil evidence of the age of the Virginia Piedmont slates: American Journal of Science, 4th series, v. 31, p. 33-44.

Weems, R.E., 2012, Richmond MSA digital geologic compilation-Hanover Academy quadrangle, Virginia: Virginia Division of Geology and Mineral Resources, 2012 VDGMR STATEMAP, scale 1:24,000.

Weems, R.E., 2013, Richmond MSA digital geologic compilation-Montpelier quadrangle, Virginia: Virginia, Division of Geology and Mineral Resources, 2012 VDGMR STATEMAP, scale 1:24,000.

Zen, E.-A., and Hammarstrom, J.M., 1984, Magmatic epidote and its petrologic significance: Geology, v. 12, no. 9, p. 515-518, accessed September 2019 at https://doi. org/10.1130/0091-7613(1984)12<515:MEAIPS>2.0.CO;2. 


\section{Appendix 1. Laser Ablation-Inductively Coupled Plasma-Mass Spectrometry (LA-ICP-MS) Methodology}

Zircon was ablated with a Photon Machines Excite 193 nanometer argon-fluoride (ArF) excimer laser in spot mode. The laser spot sizes for zircon were approximately 25 micrometers $(\mu \mathrm{m})$. Each analysis consisted of 150 total bursts with a repetition rate of 5 hertz, laser energy of approximately 3 millijoules, and an energy density of 4.11 Joules per square centimeter. Pit depths are typically less than $20 \mu \mathrm{m}$. The rate of helium carrier gas flow from the HelEx cell of the laser was $\sim 0.6$ liters per minute (L/min). Make-up argon gas (approximately $0.6 \mathrm{~L} / \mathrm{min}$ ) was added to the sample stream prior to its introduction into the plasma. Nitrogen with flow rate of 5.5 milliliters per minute was added to the sample stream to allow for significant reduction in $\mathrm{ThO}^{+} / \mathrm{Th}^{+}(<0.5$ percent) and improved the ionization of refractory thorium (Hu and others, 2008). With the magnet centered at a constant mass, the flat tops of the isotope peaks of ${ }^{202} \mathrm{Hg}$, ${ }^{204}(\mathrm{Hg}+\mathrm{Pb}),{ }^{206} \mathrm{~Pb},{ }^{207} \mathrm{~Pb},{ }^{208} \mathrm{~Pb},{ }^{232} \mathrm{Th},{ }^{235} \mathrm{U}$, and ${ }^{238} \mathrm{U}$ were measured by rapidly deflecting the ion beam with a 30 -second on-peak background measured prior to each 30 -second analysis. Raw data were reduced off-line using the Iolite 2.5 program (Paton and others, 2011) to subtract onpeak background signals, correct for U-Pb downhole fractionation, and normalize the instrumental mass bias using external mineral reference materials, the ages of which had previously been determined by isotope dilution-thermal ionization mass spectrometry. Ages were corrected by standard sample bracketing with the primary zircon reference material Temora2 (417 Ma; Black and others, 2004) and secondary reference materials FC-1 (1,099 Ma; Paces and Miller, 1993) and Plešovice (337 Ma, Sláma and others, 2008). Reduced data were compiled into probability density plots using Isoplot 4.15 (Ludwig, 2012). ${ }^{206} \mathrm{~Pb} /{ }^{238} \mathrm{U}$ ages are reported for zircons younger than approximately $1,300 \mathrm{Ma}$ and ${ }^{207} \mathrm{~Pb} /{ }^{206} \mathrm{~Pb}$ ages are used for older zircons following the recommendations of Gehrels (2012).

\section{Appendix 2. Secondary lonization Mass Spectrometry Methodology}

Zircon grains from igneous samples and from biotite-muscovite migmatitic paragneiss were analyzed by secondary ionization mass spectrometry on the U.S. Geological Survey (USGS)/Stanford sensitive high-resolution ion microprobe-reverse geometry (SHRIMP-RG), using a spot diameter of approximately 20 micrometers $(\mu \mathrm{m})$. Calculated ages are the weighted averages of concordant ages determined from the 207 -corrected ${ }^{206} \mathrm{~Pb} /{ }^{238} \mathrm{U}$ ratio and are reported at $2 \sigma$. Spot ages were considered concordant if the $2 \sigma$ error ellipse overlapped concordia on a Wetherhill plot (Spencer and others, 2016). Uncertainties on single spot analyses, when stated, are at $1 \sigma$. The 204 -corrected ${ }^{207} \mathrm{~Pb} /{ }^{206} \mathrm{~Pb}$ age was used for zircons older than $1,300 \mathrm{Ma}$ in the probability density plot for detrital zircons from sample BK601 $(n=2)$ and an analysis was considered concordant if it overlapped concordia on a Tera-Wasserburg plot for these grains. All zircon grains dated by SHRIMP-RG methods were imaged in backscatter electron (BSE) and panchromatic cathodoluminescence (CL) modes on a Hitachi SU5000 field emission scanning electron microscope after grain polishing but prior to isotopic analyses. The grains were then re-examined by the same methods after isotopic analysis. A subset of dated and undated grains from sample BK601 were imaged in ultraviolet light (365 nanometers) on a Zeiss AxioImager 
petrographic microscope prior to grain polishing (fig. $7 D$ ). Isotopic data for all analysis are given in table 3 (available online at https://doi.org/10.3133/pp1861).

Zircon grains were extracted from approximately 5-kilogram samples at the USGS in Reston, Virginia. Samples were crushed and ground in a Sturtevant jaw crusher and Bico direct-drive disk mill, respectively, and then sieved to less than $250 \mu \mathrm{m}$ (60 mesh). Particles larger than $250 \mu \mathrm{m}$ were given a second pass through the disk mill. The fraction smaller than $250 \mu \mathrm{m}$ was then passed over a Wilfley table. For samples with abundant heavy minerals, the heavy fraction was sent over the Wilfley table a second time to reduce the volume for further processing. The heavy minerals were dried immediately on a hotplate. Following removal of the most magnetic material with a hand magnet, the sample was sent through a Frantz L1 magnetic separator and lithium heteropolytungstate (LST) heavy liquid ( $\rho=2.85$ grams per cubic centimeter $\left.\left[\mathrm{g} / \mathrm{cm}^{3}\right]\right)$. The order of these two steps varied depending on the mineral assemblage of the sample. The nonmagnetic fraction heavier than LST was then put through methlyene iodide $\left(\rho=3.3 \mathrm{~g} / \mathrm{cm}^{3}\right)$, and zircons of interest were hand-picked from the sinks on a binocular microscope under incident and transmitted light. Some samples with abundant apatite or pyrite remaining in the heavy fraction were also treated with nitric acid to remove these impurities and increase the concentration of zircon for easier grain picking.

Selected zircon grains were mounted on double-sided kapton tape and fixed with Struers EpoFix epoxy in a 1-inch round cylinder. The resulting 1-inch round mount was polished with 1500 or 2500 grit sand paper to expose grain interiors. The mount was then polished on a Struers LaboPol polisher, with $6 \mu \mathrm{m}$ and then $1 \mu \mathrm{m}$ diamond suspension with a goal of polishing halfway into the grains (for more information see https://shrimprg.stanford.edu/ sample-types-and-sample-preparation).

SHRIMP-RG analyses were conducted during two separate analytical sessions in 2016 and 2017. A similar analytical setup was used in each session and measured 9 (2017) or 10 (2016) peak locations in 5 cycles on the single collector SHRIMP-RG. The spot size for all analyses was approximately $20 \mu \mathrm{m}$ in diameter and approximately $1 \mu \mathrm{m}$ in depth. Zircon standard R33 (419 Ma; Black and others, 2004) mounted with the unknowns was used to correct ${ }^{206} \mathrm{~Pb} /{ }^{238} \mathrm{U}$ ages for elemental fractionation and was run after every fourth unknown analysis. Raw data were reduced using Squid 2 (Ludwig, 2009) and plotted using Isoplot 3.75 (Ludwig, 2012). Calculated ages are the weighted averages of ages determined from the ${ }^{206} \mathrm{~Pb} /{ }^{238} \mathrm{U}$ ratio and are reported at $2 \sigma$. For ages older than 1,300 Ma (sample BK601), the ${ }^{207} \mathrm{~Pb} /{ }^{206} \mathrm{~Pb}$ age is used in plotting. Uranium and thorium concentrations are also reported for each analysis and are relative to analyses of the concentration standard MADDER (Barth and Wooden, 2010) that was mounted with each set of unknowns. 
For additional information, contact:

Director, Florence Bascom Geoscience Center U.S. Geological Survey

12201 Sunrise Valley Drive

Reston, VA 21092

or visit our website at:

https://www.usgs.gov/centers/fbgc

Publishing support provided by the West Trenton Publishing Service Center 


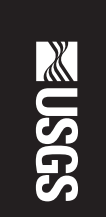

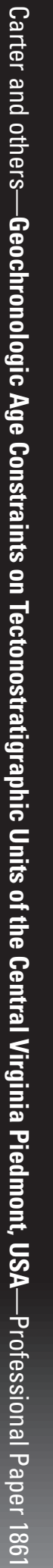

